\title{
MASTER
}

\section{Assessment of a Small Pressurized Water Reactor for Industrial Energy}

\author{
O. H. Klepper \\ L. C. Fuller \\ M. L. Myers
}

\section{OAK RIDGE NATIONAL LABORATORY}




\section{DISCLAIMER}

This report was prepared as an account of work sponsored by an agency of the United States Government. Neither the United States Government nor any agency Thereof, nor any of their employees, makes any warranty, express or implied, or assumes any legal liability or responsibility for the accuracy, completeness, or usefulness of any information, apparatus, product, or process disclosed, or represents that its use would not infringe privately owned rights. Reference herein to any specific commercial product, process, or service by trade name, trademark, manufacturer, or otherwise does not necessarily constitute or imply its endorsement, recommendation, or favoring by the United States Government or any agency thereof. The views and opinions of authors expressed herein do not necessarily state or reflect those of the United States Government or any agency thereof. 


\section{DISCLAIMER}

Portions of this document may be illegible in electronic image products. Images are produced from the best available original document. 


\section{Printed in the United States of America. Available from}

National Technical Information Service

U.S. Department of Commerce 5285 Port Royal Road, Springfield, Virginia 22161

Price: Printed Copy $\$ 5.25$; Microfiche $\$ 3.00$

This report was prepared as an account of work sponsored by the United States Government. Neither the United States nor any of its employees, nor any of its contractors, subcontractors, or their employees, makes any warranty, express or implied, or assumes any legal liability or responsibility for the accuracy, completeness or usefulness of any information, apparatus, product or process disclosed, or represents that its use would not infringe privately owned rights. 
Contract No. W-7405-eng-26

Engineering Technology Division

\begin{abstract}
ASSESSMENT OF A SMALL PRESSURIZED WATER
\end{abstract}
REACTOR FOR INDUSTRIAL ENERGY

O. H. Klepper L. C. Fuller

M. L. Myers

Manuscript Completed - October 4, 1977

Date Published - October 1977

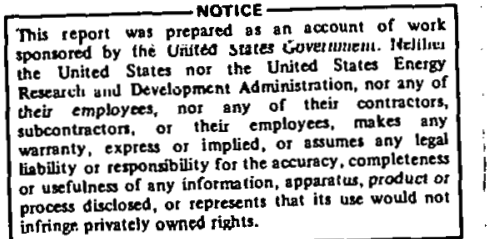

process disclosed, or represents
infingt privately owned rights.

Prepared by the OAK RIDGE NATIONAL LABORATORY

Oak Ridge, Tennessee 37830

operated by

UNION CARBIDE CORPORATION

for the

DEPARTMENT OF ENERGY 
THIS PAGE

WAS INTENTIONALLY

LEFT BLANK 
CONTENTS

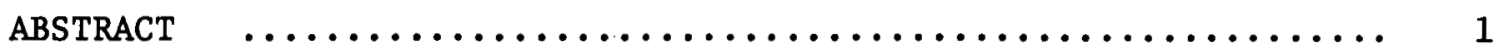

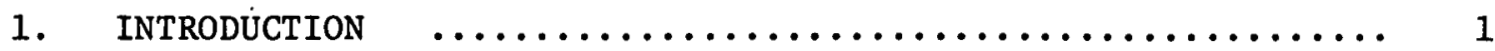

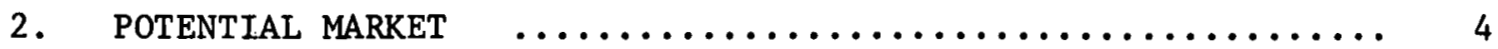

3. RELIABILITY CONSIDERATIONS $\ldots \ldots \ldots \ldots \ldots \ldots \ldots \ldots \ldots \ldots \ldots$

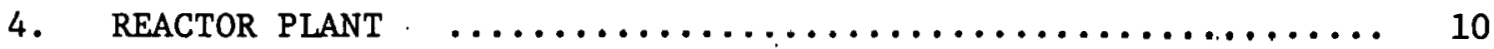

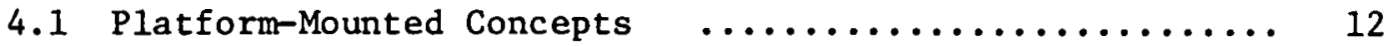

4.2 Land-based Concepts $\ldots \ldots \ldots \ldots \ldots \ldots \ldots \ldots \ldots \ldots \ldots \ldots$

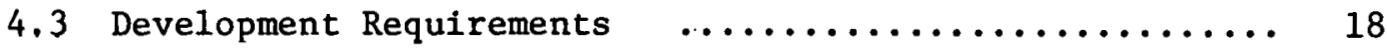

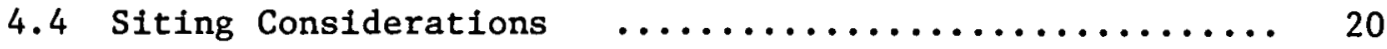

5. ALTERNATIVE FOSSIL-FIRED STEAM SUPPLIES $\ldots \ldots \ldots \ldots \ldots \ldots \ldots 22$

5.1 Steam Generators Fueled with Eastern Bituminous

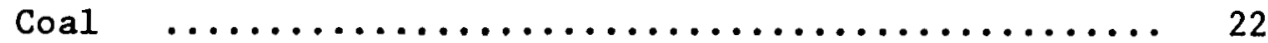

5.2 Steam Generators Fueled with Western Low-Sulfur

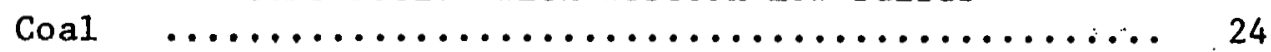

6. COMPARISON BETWEEN NUCLEAR AND FOSSIL-FIRED PROCESS

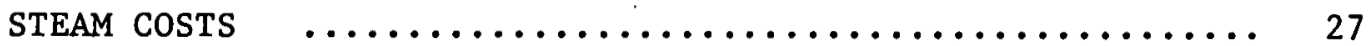

6.1 Process Steam Plant Capital Costs $\ldots \ldots \ldots \ldots \ldots \ldots \ldots . . \ldots 27$

6.2 Operating, Maintenance and Fuel Costs $\ldots \ldots \ldots \ldots \ldots . . \ldots 27$

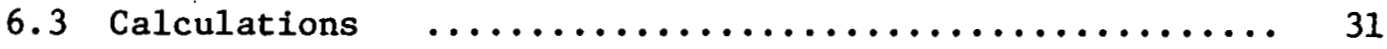

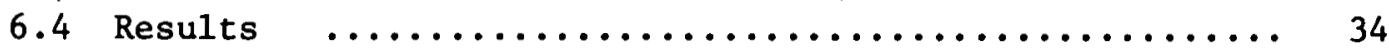

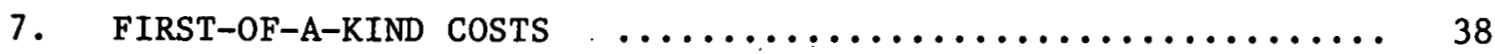

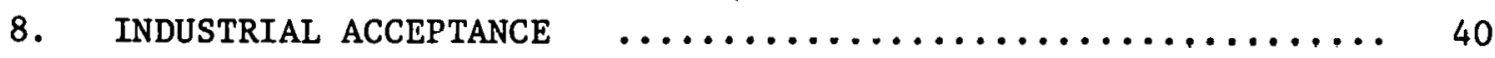

9. CONCLUSIONS AND RECOMMENDATIONS $\ldots \ldots \ldots \ldots \ldots \ldots \ldots \ldots \ldots . \ldots . \ldots . \ldots$

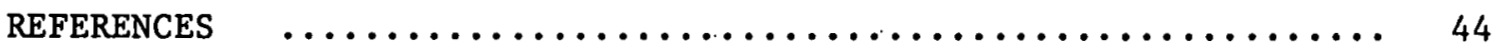




\section{ASSESSMENT OF A SMALL PRESSURIZED WATER REACTOR FOR INDUSTRIAL ENERGY}

O. H. Klepper L. C. Fuller

M. L. Myers

\section{ABSTRACT}

An evaluation of several recent ERDA/ORNL sponsored studies on the application of a smal1, $365 \mathrm{MW}(t)$ pressurized water reactor for industrial energy is presented. Preliminary studies have investigated technical and reliability requirements; costs for nuclear and fossil based steam were compared, including consideration of economic inflation and financing methods. For base-load industrial steam production, small reactors appear economically attractive relative to coal fired boilers that use coal priced at $\$ 30 /$ ton.

\section{INTRODUCTION}

Some background datal needed to assess the dimensions of industrial energy requirements include the following: The industrial sector is the largest energy user in the United States, requiring about $40 \%$ of the national consumption; natural gas and petroleum furnish about $80 \%$ of industrial fuels. Roughly two-thirds of this Nation's industrial energy is consumed by the primary metals, chemicals, petroleum, food, paper, and stone industries. The chemicals, petroleum, and primary metals industries are of particular interest, since these include many plants and industrial complexes with sizable energy requirements where the introduction of alternative energy sources might reduce consumption of oil and gas significantly. A breakdown of industrial energy by form indicates that process steam is the most commonly used kind and amounts to nearly $17 \%$ of the total national energy use. This is equivalent to twothirds of the energy consumed in the United States to produce electric power.

Coal and nuclear fuels appear to have the best potential for meeting near-term energy demands (up to the year 1990); moreover, they provide an adequate long-term resource base. Large commercial nuclear power plants could offer industrial steam and electricity at a relatively low 
cost among present energy supplies. However, the mismatch between the large [2000-3800 MW(t)] output of currently marketed central station reactors and the consumption rate of individual industrial plants will limit applications to joint uses of a nuclear power station. ${ }^{2}$ One desirable arrangement is for an electric utility to generate both electrical energy for the grid and pipeline steam for nearby industries. Amother solution would be to use small industry-owned nuclear reactors which would match the load demand of single large energy user plants, thus avoiding the institutional problems arising from use of a single utilily=uwned plant to serve a number of industries. Furthermore, the planning and construction of small reactors could quite likely be accomplished within about two thirds of the time required for large central station reactors.

Three or four years ago, conventional wisdom held that nuclear power plants must be very large to be competitive with fossil fuels. This situation has changed markedly in most countries within recent years as oil and gas are becoming increasingly scarce and costly and the supply of ecologically acceptable fuels has fallen behind demand.

Results of previous studies ${ }^{1,3,4}$ indicate that a small [300-400. $M W(t)$ ] industrial energy pressurized water reactor (PWR) might be competitive with alternative coal-based process steam sources. The analyses were based on conceptual design and cost estiuiatés for land-based and platform-mounted versions of the small [314 MW( $t)$ ] Consolidated Nuclear Steam Generator (CNSG) reactor that had been developed previously by Babcock and Wilcox for ship propulsion. In order to develop a firmer basis for ERDA planning, more detailed designs and cost estimates were prepared by Babcock and Wilcox for industrial applications of this reactor type. The results of this study were presented by Babcock and Wilcox in a report ${ }^{5}$ entitled A Smal1 Pressurized Water Reactor for Process Energy, Babcock and Wilcox, report BAW-1428 (June 1976).

The industrial reactor plant designs developed in that study are the subjects of this assessment.

While the $B \& W$ effort was underway, a number of additional studies related to industrial reactors were sponsored by ERDA. These addressed 
questions of market potential, 6 rellability requirements, 7,8 and the economics of competing coal-fired industrial power sources. 9 Selected results from these sources will be cited in order to add perspective to the present evaluation. 


\section{POTENTIAL MARKET}

The Dow Chemical Company, under contract to the Oak Ridge National Laboratory (ORNL), completed a survey of the potential market ${ }^{6}$ for industrial energy supplied by nuclear reactors. A specific segment of industrial process heat use was examined in detail to identify individual plant locations throughout the United States where sizable quantities of industrial steam are used. No attempt was made to determine if these sites were compatible with reactor licensing requirements. Five major industries have been studied - Paper, Chemicals, Petroleum, Rubber, and Primary Metals. Process steam applications within the industries studied involve temperatures from about $38^{\circ} \mathrm{C}\left(100^{\circ} \mathrm{F}\right)$ up to about $232^{\circ} \mathrm{C}\left(450^{\circ} \mathrm{F}\right)$. Although steam is often produced at temperatures above $232^{\circ} \mathrm{C}\left(450^{\circ} \mathrm{F}\right)$, the high temperatures/high pressure steam is first used for electrical power generation and then extracted at lower pressures for process heat. Also, much of the steam use in the $232^{\circ} \mathrm{C}\left(450^{\circ} \mathrm{F}\right)$ temperature range is in turbines or reciprocating engines, driving pumps, compressors, etc. These applications may be converted to electrical drive as steam costs increase. Thus, it is estimated that at least $85 \%$ of the industrial steam heat requirement is below $204^{\circ} \mathrm{C}\left(400^{\circ} \mathrm{F}\right)$ and within the range available from conventional nuclear light water reactors.

For the industries investigated, representing $75 \%$ of the total industrial steam consumption, the individual plant locations within the U.S. using steam in large quantities have been located and characterized as to fuel requirements. Figure 1 shows the 119 locations within the United States where there exists a concentrated industrial steam load of at least $63 \mathrm{~kg} / \mathrm{s}(500,000 \mathrm{lb} / \mathrm{hr})$ [ $150 \mathrm{MW}(\mathrm{th})]$ within a $3.2 \mathrm{~km}$ (2 mile) radius, a load that, when combined with industrial electrical power requirements, appears compatible with the power level of small reactors. An additional 24 locations have a combined industrial steam requirement of at least $252 \mathrm{~kg} / \mathrm{s}(2,000,000 \mathrm{lb} / \mathrm{hr})[\sim 600 \mathrm{MW}(\mathrm{t})]$ within a circle of $16 \mathrm{~km}$ (10 miles) diameter, and 19 further locations have a combined requirement of at least $504 \mathrm{~kg} / \mathrm{s}(4,000,000 \mathrm{lb} / \mathrm{hr})$ [ 1200 MW(t)] within a circle of $32 \mathrm{~km}$ ( 20 miles) diameter. Industrial concentrations located 


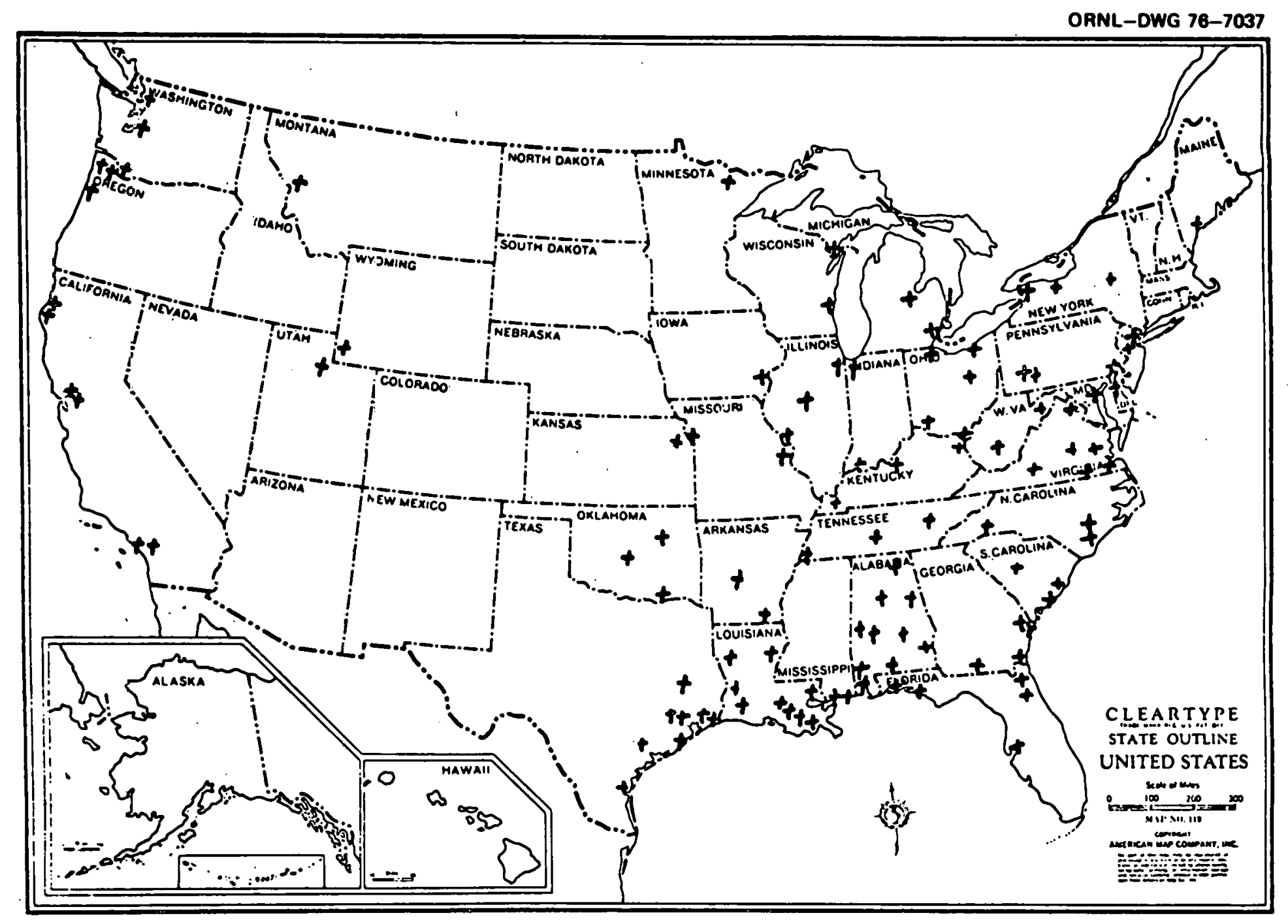

Fig. 1. Locations with industrial steam demand of at least $63 \mathrm{~kg} / \mathrm{s}$ $(500,000 \mathrm{lb} / \mathrm{hr})$ within a $3.2 \mathrm{~km}$ (2 mile) radius. 
near navigable waterways number 9.7. The sites identified in the survey are listed by state In Table 1 . 
Table 1. Summary of potential sites for Industrial energy reactors

\begin{tabular}{|c|c|c|c|c|c|c|c|c|}
\hline \multirow[b]{2}{*}{ State } & \multirow{2}{*}{$\begin{array}{c}\text { No. } \\
\text { of } \\
\text { sites } \\
\end{array}$} & \multicolumn{2}{|c|}{ Total steam load } & \multirow{2}{*}{$\begin{array}{c}\text { Elec. } \\
\text { MW }\end{array}$} & \multicolumn{2}{|c|}{ Energy use } & & \multirow{2}{*}{$\begin{array}{c}\text { S1tes with } \\
\text { navigable } \\
\text { waterway } \\
2 \text { access }\end{array}$} \\
\hline & & $\begin{array}{l}\text { Tota } \\
\mathrm{kg} / \mathrm{s} \\
\end{array}$ & $\begin{aligned} \text { steam load } \\
\left(10^{6} \mathrm{lb} / \mathrm{hr}\right)\end{aligned}$ & & $10^{9} \mathrm{~kJ} /$ day & $\begin{array}{r}\text { Fuel } \\
\quad\left(10^{9}\right. \\
\end{array}$ & Btu/day) & \\
\hline Alabama & 8 & 1590 & $(12.6)$ & 913 & 367 & & $348)$ & 7 \\
\hline Arkansas & 3 & 720 & $(5.7)$ & 174 & 168 & & $159)$ & 0 \\
\hline Cal1fornia & 9 & 2320 & $(18.4)$ & 694 & 550 & & $521)$ & 6 \\
\hline Connecticut & 1 & 90 & $(0.7)$ & 8 & 21 & ( & 20) & 1 \\
\hline Delaware & 1 & 260 & ( 2.1$)$ & 102 & 62 & ( & 59) & 1 \\
\hline Florida & 7 & 1460 & $(11.6)$ & 464 & 346 & & $328)$ & 6 \\
\hline Georgia & 7 & 1270 & (10.1) & 643 & 301 & & $285)$ & 6 \\
\hline Iowa & 1 & 90 & $(0.7)$ & 62 & 21 & ( & 20) & 1 \\
\hline Idaho & 1 & 100 & $(0.8)$ & 45 & 24 & ( & 23) & 0 \\
\hline Illinois & 4 & 1390 & $(11.0)$ & 347 & 329 & & $312)$ & 2 \\
\hline Indlana & 3 & 1500 & (11.9) & 2220 & 354 & & $336)$ & 2 \\
\hline Kentucky & 2 & 190 & $(1.5)$ & 35 & 45 & ( & 43) & 2 \\
\hline Loulstana & 15 & 5720 & $(45.4)$ & 3227 & 1.353 & 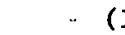 & 1283) & 12 \\
\hline Maryland & 2 & 350 & $(2.8)$ & 298 & 83 & ( & 79) & 1 \\
\hline Maine & 6 & 600 & $(4.8)$ & 201 & 144 & & $137)$ & 0 \\
\hline M1 chigan & 5 & 2320 & $(18.4)$ & 666 & 251 & & $238)$ & 4 \\
\hline Minnesota & 2 & 190 & $(1.5)$ & 69 & 44 & i & 42) & 1 \\
\hline Missour1 & 2 & 200 & $(1.6)$ & 50 & 47 & ( & 45) & 2 \\
\hline M1ssiss1ppi & 3 & 620 & $(4.9)$ & 198 & 151 & & 143) & 1 \\
\hline Montana & 1 & 160 & $(1.3)$ & 24 & 39 & ( & 37) & 0 \\
\hline North Carolina & 6 & 760 & $(6.0)$ & 207 & 178 & & 169) & 3 \\
\hline New Jersey & 3 & 720 & $(5.7)$ & 169 & 170 & & $161)$ & 3 \\
\hline New York & 8 & 1030 & $(8.2)$ & 566 & 244 & & $231)$ & 3 \\
\hline Oh10 & 6 & 800 & $(6.4)$ & 266 & 192 & ( & $182)$ & 3 \\
\hline Oklahoma & 2 & 290 & $(2.3)$ & 91 & 69 & ( & 65) & 0 \\
\hline Oregon & 4 & 340 & $(2.7)$ & 163 & 83 & ( & 79) & 2 \\
\hline Pennsylvania & 4 & 970 & $(7.7)$ & 666 & 229 & & $217)$ & 3 \\
\hline South Carolina & 3 & 830 & $(6.6)$ & 332 & 200 & & $190)$ & 2 \\
\hline Tennessee & 3 & 250 & $(2.0)$ & 487 & 59 & & $56)$ & 2 \\
\hline Texas & 17 & 9880 & $(78.4)$ & 4158 & 2334 & & $2212)$ & 10 \\
\hline Utah & 2 & 300 & $(2.4)$ & 228 & 73 & i & $69)$ & 0 \\
\hline VIrginia & 7 & 790 & $(6.3)$ & 155 & 189 & & $179)$ & 1 \\
\hline Washington & 5 & 600 & $(4.8)$ & 260 & 144 & & $137)$ & 5 \\
\hline Wisconsin & 2 & 180 & $(1.4)$ & 58 & 41 & & 39) & 1 \\
\hline West Virginia & 4 & 910 & $(7.2)$ & 390 & 216 & ( & $205)$ & 4 \\
\hline Wyoming & 3 & 380 & $(3.0)$ & 74 & 89 & & $84)$ & 0 \\
\hline TOTAL & 162 & 40,170 & 319.1 & 18,710 & 9210 & & 8733 & 97 \\
\hline
\end{tabular}




\section{RELIABILITY CONS IDERATIONS}

In the application of alternative industrial process energy systems, reliability can be of major importance. A study ${ }^{7}$ of three large industries to determine process energy system reliabilities that were actually experienced during 1973 and 1974 gives insight into service continuity requirements. It is believed the estimated reliability of the steam-supply system at companies studied represents an operating condition that is at least minimally acceptable to them.* Thus, results reported should be viewed as "what actually happened" rather than "what should have happened" under ideal economic conditions. Furthermore, these results were ohtained from some of the largest plants within the industries studied.

Based on process steam-system reliabilities obtained from data reported in the study questionnaire, it is concluded that sources of process steam in the chemical industry were about $98 \%$ reliable. That is, they were capable of meeting or exceeding forecast steam production requirements on a continuous basis except for 7 days per year on the average. Individual plant reliabilities ranged from 100 to $89 \%$, so there is considerable variation about the average reliability of $98 \%$. These relatively high rellabillties were attained by maintaining a sizable number of back-up steam supplies on-line.

Concerning the ninc pctroleum refineries in the survey, thelr average reliability was roughly $92 \%$. This corresponds to 29 days of the year that scheduled production of an average refinery had to be curtailed because of random boller outages and steam supply outages caused by operator errors, violent storms, etc. Probably a more representative estimate of actual reliability is given by the modal response which was $96 \%$. This figure divides responses into two halves such that one group of refineries experlenced rellabilities higher than $96 \%$ and the other group had reliabilities lower than $96 \%$. Because the nine refineries in this study accounted

*Bccauge the year studied (1973 Lu 1974) was only a "snanshot" of long-term performance, representatives of some companies stated that this particular year provided the highly favorable picture of their operations. Others commented that the 1973 to 1974 period was the worst year in their history relative to unscheduled equipment outages, violent storms, etc. 
for better than $10 \%$ of all steam produced at refinerles in 1973 and 1974, it is belleved that a $96 \%$ reliable steam supply system is quite reasonable as a representative industry-wide operating parameter.

Finaily, reliabilities of process energy systems in the primary metals industry were found to be $100 \%$. This means that for the perlod 1973 to 1974 , there were no interruptions in process energy that resulted in the curtailment of scheduled production. The sample size was small, and thus general conclusions appear to be inappropriate.

This survey sample represents a modest fraction of the three major industries studied; however, it is believed to be representative of current reliability experience with large plants. For those applications, an energy supply system capable of meeting load demand $96-99 \%$ of the time appears reasonable. Reliability estimates ${ }^{8}$ made under a number of simplifying assumptions indicate that multiple nuclear units or a combination of nuclear and fossil-fired plants could provide adequate reliability to meet industrial requirements for continuity of service. 


\section{REACTOR PLANT}

One of the near-term nuclear alternatives investigated was based on an already existing reactor design, a $314 \mathrm{MW}(t)$ ship propulsion reactor being developed for the U.S. Maritime Administration. A $314 \mathrm{MW}(t)$ CNSG plant concept [with a stretch capability of $365 \mathrm{MW}(t)$ ] was evaluated assuming conventional construction methods; in addition, a concept for a barge-mounted $314 \mathrm{MW}(t)$ CNSG plant was developed to determine if construction time or costs might be reduced utilizing repetitive platform construction in a shipyard.

Work on the Consolidated Nuclear Steam Generator (CNSG) for nuclear ship propulsion has been underway at the Babcock and Wilcux Company9,10 since 1960. Some of the unique features of the plant design, depicted in Fig. 2, including the once-through steam generator housed within the reactor vessel, have already been demonstrated in the Federal German Republic nuclear ship "Otto Hahn," that has operated successfully since 1969. The U.S. Maritime Commission has continued to sponsor work in the areas of design, testing, and evaluation of the CNSG concept, and current efforts are directed toward a $314 \mathrm{MW}(t)$ application for propelling a 600,000 ton tanker.

The CNSG pressurized water reactor is essentially based on current technology, 5 and only limited development would be required for process heat applications in the 300-400 $\mathrm{MW}(\mathrm{t})$ power range. The reactor is of the integral type which has the core and steam generator inside the reactor vessel and an external, electrically heated pressurizer. The reactor coolant system is comprised of the reactor vessel, a set of modular once-through steam generators, four vertically mounted, wetted-motor reactor coolant pumps, and the pressurizer and interconnecting pip1ng. The steam generators are positioned inside the reactor vesse $\mathrm{L}$ in an annulus above and radially outside the core. The reactor coolant pumps are mounted in the reactor vessel head, above the steam generators, with their impellers and diffusers in the steam generator annulus.

Reactor coolant travels down through the steam generator tubes, transferring heat to the feedwater and the steam being generated on the shell 


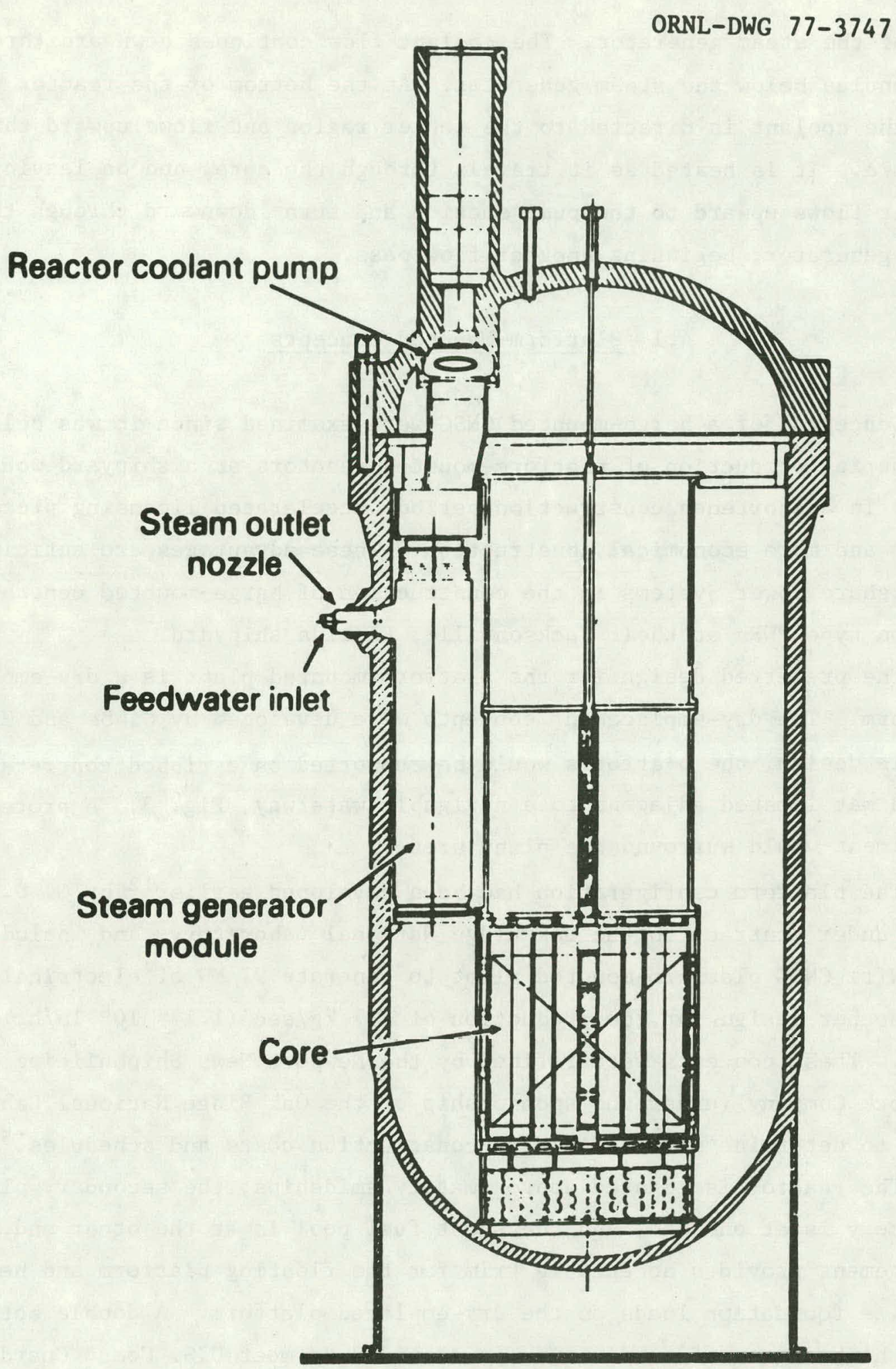

Fig. 2. CNSG arrangement. 
side of the steam generator. The coolant flow continues downward through the annulus below the steam generator. At the bottom of the reactor vessel, the coolant is directed to the center region and flows upward through the core. It is heated as it travels through the core, and on leaving the core it flows upward to the pump suction and turns downward through the steam generator, beginning another flow pass.

\subsection{Platform-Mounted Concepts}

Concepts for a barge-mounted CNSG were examined since it was believed that series production of platform-mounted reactors at a shipyard would result in a shortened construction period, accelerated licensing procedures, and more economical construction. These advantages are anticipated by Offshore Power Systems in the construction of barge-mounted centralstation type PWRs at their Jacksonville, Florida shipyard.

The preferred design for the platform-mounted plant is a dry-emplaced platform. The dry-emplacement concepts were developed by Gibbs and Hill.11 In this design, the platforms would be supported on a ribbed concrete foundation mat located adjacent to a navigable waterway, Fig. 3. A protective embankment would surround the plant area.

The platform configuration had been developed earlier ${ }^{12}$ by G. G. Sharp, Inc., under contract to the Oak Ridge National Laboratory, and included a 314 MW( $t$ ) CNSG platform-mounted plant to generate 91 MW of electrical power, and another design for the production of $137 \mathrm{~kg} / \mathrm{sec}\left(1.1 \times 10^{6} \mathrm{lb} / \mathrm{hr}\right)$ of steam. These concepts were refined by the Newport News Shipbuilding and Dry Dock Company (under the sponsorship of the Oak Ridge National Laboratory) to determine more definitive construction costs and schedules. 5

The reactor is located approximately amidships; the secondary plant machinery is at one end, and the spent fuel pool is at the other end. This arrangement provides acceptable trim for the floating platform and helps equalize foundation loads on the dry-emplaced platform. A double bottom and a high degree of subdivision is provided to meet U.S. Coast Guard requirements.

The control room, work spaces, laboratories, and preparation rooms are located in the house structure between the containment and the secondary 


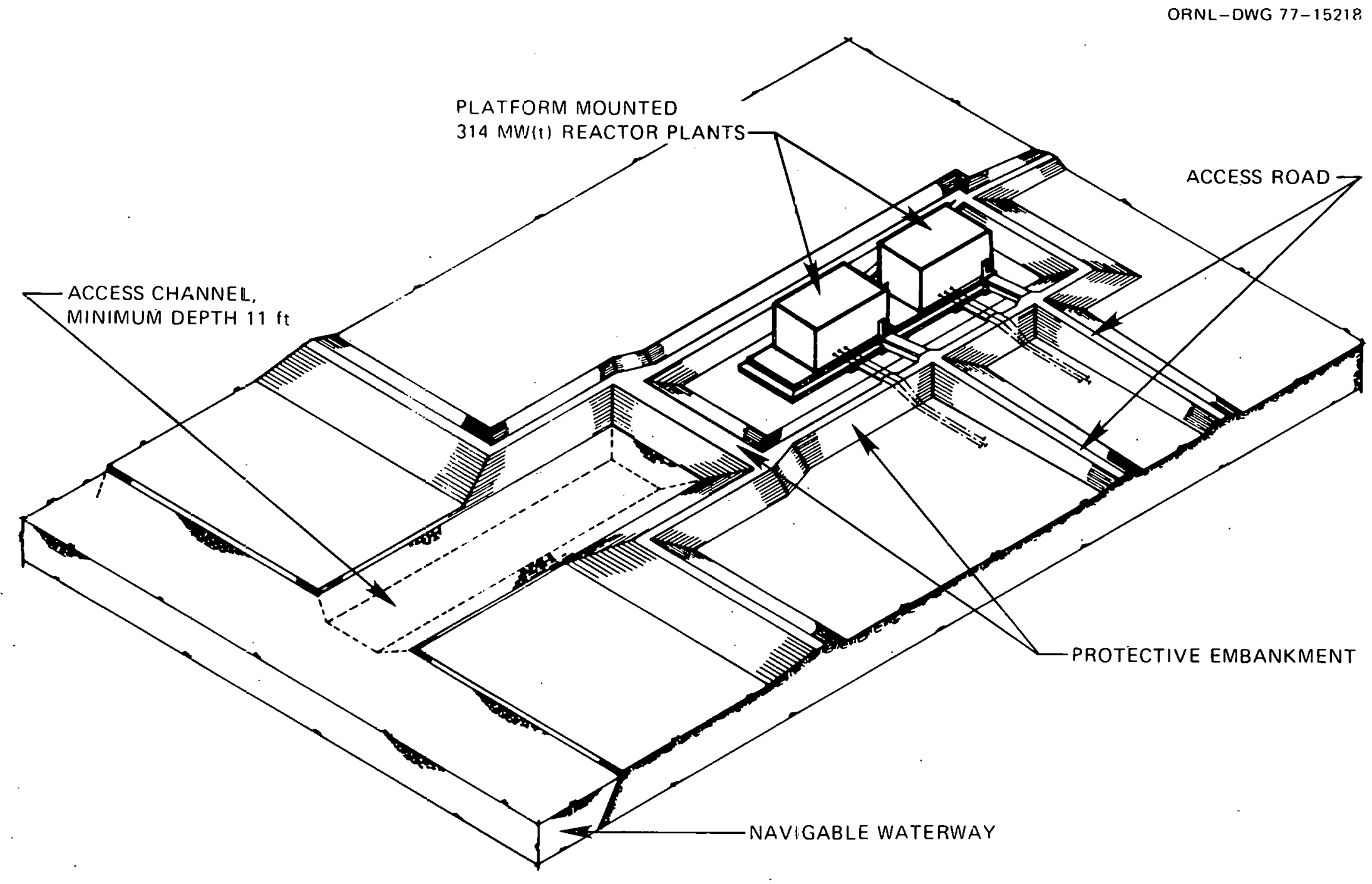

Fig. 3. Lry emplacement concept for two barge-mounted nuclear plants. 
plant area. The resulting platform has a $32-m(105-f t)$ beam, a $10-m$ (32-ft 6-in.) depth and a 2.3-m (7-ft 6-in.) innerbottom helght. The overall height of the platform and house is $41 \mathrm{~m}(134 \mathrm{ft})$. The platform lengths are $75 \mathrm{~m}(245 \mathrm{ft}$ ) for a process steam plant and $81 \mathrm{~m}$ (265

$f t$ ) for a turbine-generator plant.

Water shielding is used instead of the conventional concrete shielding for both the containment, biological, and secondary shielding. Water shielding has been used aboard nuclear powered ships, and the containment and biological shielding considered here is taken from the maritime CNSG ship design. The containment consists of two concentric steel cylinders surrounding the reactor shielding water between them. Additional shielding water is provided in tanks above and below the reactor. Secondary shielding consists of a double-walled steel structure completely enclosing the machinery box and containing water shielding. The water shielding concept was chosen for the design since it is amenable to shipyard production and minimizes work required at the emplacement site.

The platform is designed to meet in-transit limitations of:

1. 32-m (105-ft) maximum beam in order to clear certain locks in the major inland waterways.

2. 3.3-m (11-ft) maximum draft 11m1zac1on w1th1n the Intracoastal waterways.

3. 21-m (68-ft) maximum house height above water levẹl to clear bridges.

In order to meet the bridge height limitation, it is necessary to install the upper portions of the house after the platform has reached the operating site.

It had been expected that construction of platform-mounted units at a shipyard would reduce reactor plant costs. However, Ref. 5 showed that capital costs for the platform-mounced conceprs consldered in that sludy were consistently higher than for land-based designs at identical power output. For the process-steam-only design, the platform-mounted plant nth-of-a-kind capital costs were $26 \%$ higher than for a land-based concept. In a configuration for the production of electricity only, the corresponding difference amounted to $41 \%$. The major cost difference between landbased and platform-mounted concepts was contributed by relatively higher 
costs for installing the reactor in the platform. The shipyard cost estimates were not sufficiently detailed to identify the specific contributing factors.

The time required for actual field construction is about two years shorter for the platform unit; however, this is of little practical advantage since the overall project schedule is dominated by a 5-yr leadtime required for delivery of the reactor vessel. Thus, the project schedule is about six years for nth-of-a-kind land-based, as well as for platform-mounted plants. Floating plants may, however, be preferable at specific sites, such as those subject to subsidence or ground faulting, where a platform-mounted plant may present a distinct advantage over a land-based configuration.

For a broad-based application to meet industrial energy needs, the land-based concepts appear preferable because these are more compatible with common industrial sites and they offer lower costs, and thus the balance of this assessment will be confined to consideration of landbased industrial energy sources.

\subsection{Land-based Concepts}

Major reactor parameters for the $365 \mathrm{MW}(t)$ design are shown in Table 2. The reactor plant concept ${ }^{5}$ developed by United Engineers under contract to the Oak Ridge National Laboratory is depicted in Fig. 4.

Two approaches for providing process energy from the reactor plant were developed; (1) electrical power only, $110 \mathrm{MW},(2)$ steam only, 365 MW $(t)$. A combination of electrical power and steam is also feasible; however, a meaningful economic evaluation of a dual-purpose plant would have to consider the detailed steam and electrical demand of the particular application.

In process heat applications, conservative design practice provides for an additional loop or separation barrier between the reactor coolant (primary system) and the process steam to minimize the possibility of radioactive contamination of the process steam. Even relatively small levels of process steam activity may not be acceptable in many processes due to the nature of the processes being performed (e.g., manufacturing of pharmaceuticals, radiation sensitive chemicals, etc.). 
Table 2. Consolidated nuclear steam generator reactor parameters

\begin{tabular}{|c|c|}
\hline Reactor type: & Pressurized Wacer Rèactor \\
\hline Thermal rating: & $365 \mathrm{MW}(\mathrm{th})$ \\
\hline System pressure: & $15,510 \mathrm{kPa}(2250$ psia $)$ \\
\hline Core inlet temperature: & $300^{\circ} \mathrm{C}\left(572^{\circ} \mathrm{F}\right)$ \\
\hline Core outlet temperature: & $309^{\circ} \mathrm{C}\left(589^{\circ} \mathrm{F}\right)$ \\
\hline Maximum linear heat rate $(100 \%)$ & $53 \mathrm{~kW} / \mathrm{m}(16.1 \mathrm{~kW} / \mathrm{ft})$ \\
\hline Boiler feedwater temperature: & $204^{\circ} \mathrm{C}\left(400^{\circ} \mathrm{F}\right)$ \\
\hline Total SG flow: & $183 \mathrm{~kg} / \mathrm{s}\left(1.45 \times 10^{6} \mathrm{lb} / \mathrm{hr}\right)$ \\
\hline Steam side design temperature: & $343^{\circ} \mathrm{C}\left(649^{\circ} \mathrm{F}\right)$ \\
\hline Steam side operating temperature: & $281^{\circ} \mathrm{C}\left(538^{\circ} \mathrm{F}\right)$ \\
\hline Steam side operating pressure: & $4830 \mathrm{kPa}$ (700 psia) \\
\hline Electric capability: & $110 \mathrm{MW}(\mathrm{e})$ \\
\hline Fue1 type: & Zircaloy-clad $\mathrm{UO}_{2}$ \\
\hline Fuel life in core: & 4.5 years \\
\hline Refueling interval: & 1.5 years \\
\hline
\end{tabular}




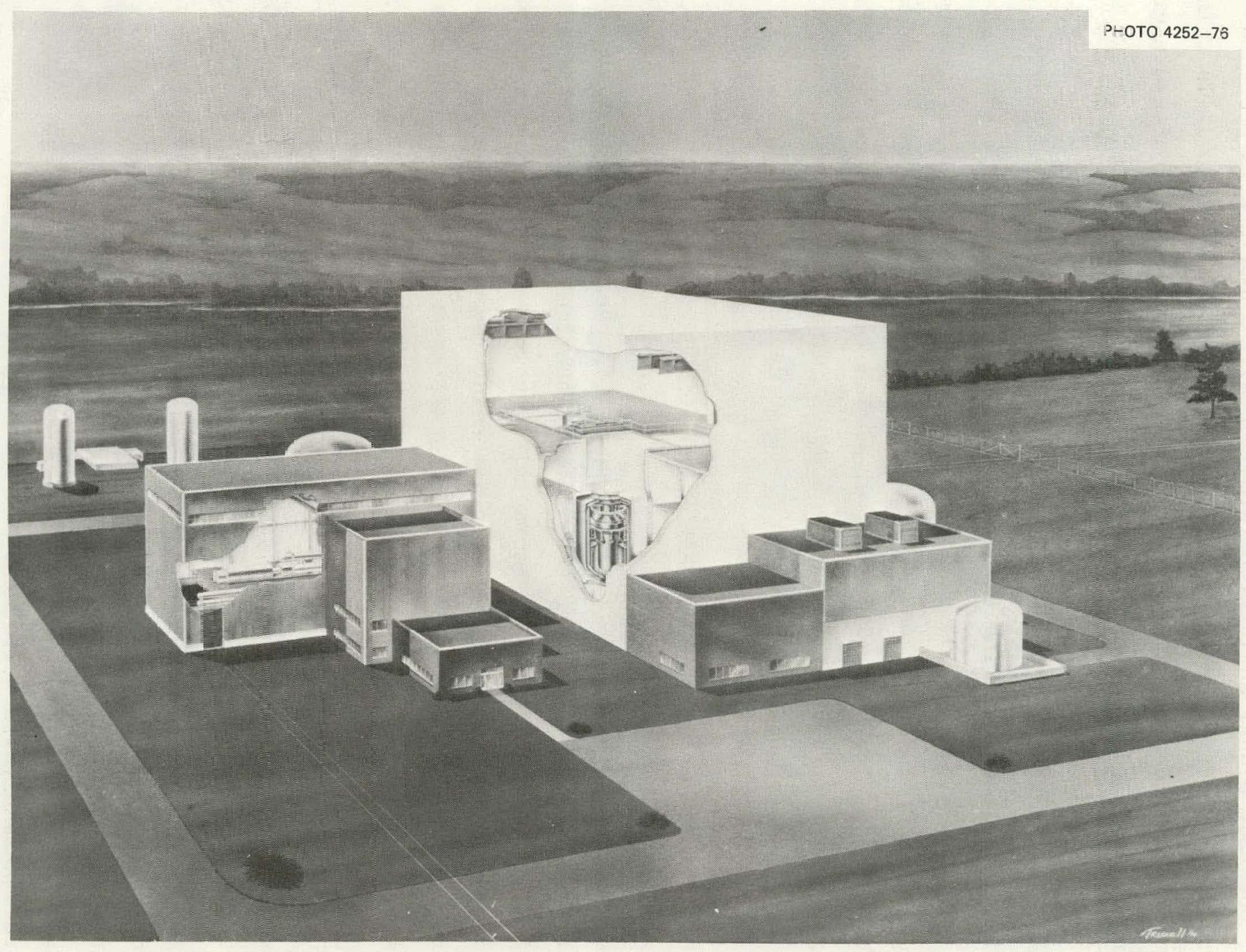

Fig. 4. 365 MW(t) land-based CNSG reactor plant. 
A precedent of sorts has been set at the Midland, Michigan Nuclear Power Station that will provide process steam for the Dow Chemical Company. For that plant, an intermediate loop with reboilers is provided to isolate this primary reactor coolant from the process steam. In this design of the CNSG process steam plant, four reboilers and one feedwater heater are provided. The reboilers are U-tube and shell heat exchangers with the secondary steam from the CNSG condensing in the tubes and the process fluid heated on the shell side. All four reboilers operate in parallel with steam entering the boilers from the CNSG at $4830 \mathrm{kPa}$ (700 psig) and $281^{\circ} \mathrm{C}\left(538^{\circ} \mathrm{F}\right), 19^{\circ} \mathrm{C}\left(35^{\circ} \mathrm{F}\right)$ superheat and leaving just slight $1 \mathrm{y}$ subcooled $258^{\circ} \mathrm{C}\left(497^{\circ} \mathrm{F}\right)$ at $4650 \mathrm{kPa}(675 \mathrm{psia})$. The total flow rate on the tube side is $189 \mathrm{~kg} / \mathrm{s}\left(1.5 \times 10^{6} 1 \mathrm{bm} / \mathrm{hr}\right)$. The feedwater heater is a straight tube heat exchanger that is used to further cool the secondary water from 258 to $206^{\circ} \mathrm{C}\left(497\right.$ to $403^{\circ} \mathrm{F}$ ) while heating the process water.

\subsection{Development Requirements}

Development of the CNSG for nuclear ship propulsion has been underway since the early 1960s, and contract engineering development by the Maritime Administration for its commercial nuclear ship program has proceeded since 1969. A preapplication licensing review has been carried forward with the NRC to explore licensing aspects and requirements.

The CNSG design is based on current technology, and only $11 \mathrm{mlted}$ development is required. 'I'he Maritime Administration sponsored cest and evaluation programs that have been completed, are underway, or are required in the future to demonstrate either the adequacy of the CNSG design or the margin of conservatism of a proven design are discussed below:

1. Upper Internals Flow Test - Flow characteristics and distribution in the upper internals region have been studied in vessel model flow tests.

2. Fuel Assembly - A mechanical and hydraulic cvaluation of the CNSG fuel assembly was performed.

3. Control Rod Extension Guide Bearing Test - Wear and friction tests have been run to evaluate two bearing materials and two shaft 
materials. The best bearing-shaft combination has been selected on the basis of resistance to wear.

4. Upper Internals Vibration Test - This test will be required in the future to investigate the possibility of flow-induced vibration in a full-scale upper guide tube structure under simulated primary conditions.

5. Vesse1 Mode1 Flow Test - With the use of a model of the reactor vesse1, the full primary flow path (including a dummy core and dumn steam generator modules) will be examined.

6. Pump Procurement and Test - A future design and test program will provide a pump with the heat flow and inertia characteristics required for a CNSG. Testing is required so that all safety and technical requirements can be demonstrated.

7. Reactor Coolant Temperature Sensor Evaluation - A future investigation will be performed to determine to what extent radiation will affect the operation and life of the specially designed platinum resistance temperature detectors (RTDs). Due to the design of the CNSG, RTDs are needed that are longer than existing designs, able to withstand flow-induced vibrations, and capable of operating effectively in high radiation fields.

8. Instrumentation and Control Hardware Qualification - Environmental qualification of safety-related equipment will be required by the NRC.

9. Fuel Assembly/Control Rod Drive Mechanism Life Testing - This future project involves the fabrication of prototype fuel assemblies, control rods and drives, and associated life testing.

10. Pressure Suppression Containment Tests - (Cost for this test has not been establi.shed and it is not included in the development costs cited below.)

11. Manufacturing Developments - The following items require further study to improve fabrication techniques and to confirm the CNSG design:

a. Steam generator tube-to-tubesheet welding,

b. Upper guidetube structure fabrication,

c, Steam generator tube plugging,

d. Reactor vessel/steam generator/internals interfacing.

Additional testing required for the PE-CNSG that is not in the scope of the presently planned CNSG programs includes: 
1. Control Rod Drive Mechanism (CRDM) Driveline Tests - The program will demonstrate the acceptability of shorter than standard control components and longer extension shaft assemblies.

2. Underwater Steam Generator Tube Inspection - Detalled maintenance procedures for the steam generator should be developed. These would specify inspection techniques and provide for engineering testing of remote tube plugging techniques. Such techniques would reduce the time required for periodic plant inspections.

The cost of the above development work has not been estimated in detail. If CNSG shipboard reactors precede industrial applications, tests and evaluations for the industrial plant may cost about one million do1lars (1976). In the absence of a Maritime development program, the corresponding costs may range from 7 to 9 million dollars.

\subsection{S1ring Consideracions}

The prospect of using nuclear power reactors for process heat raises the general question as to whether it is reasonable to expect that such plants could be located safely in industrial areas. For the purpose of providing practical guidance on siting, representative industrially developed regions near the Houston Ship Channel-Galveston Bay area in Tex= as and areas along the lower Mississippi River in Louisiana were evaluated earlier. This studyl consisted of a survey of population distributions and densities throughout these two areas.

The surveys showed that from a population viewpoint, almost all the areas scanned are much better than certain sites already accepted by NRC for central station reactors. Of all the Texas areas surveyed, only small areas along the west and south edges of the quadrangle covering the Houston Ship Channel would be of questionable acceptability. In Louisiana, a small central area in Baton Rouge and the central city of New Orleans are unfavorable.

The population density in regions near industrial energy users will often be quite non-uniform. If all other qualities of alternative sites were equal, one would want to choose the site having the lowest population risk. The NRC would give some consideration to this factor. Conversely, it is important to recognize that the NRC acceptance of existing nuclear 
power plant sites has taken such alternatives into account and would, indeed, in the future make allowance for the fact that a plant may need to be in a particular location in order to be useful. The Midland nuclear plant, which will supply process steam to an industrial facility, would probably have been. located farther from the city. of Midland had there not been a special need in that case. Other factors, such as size of plant, also favor the industrial process heat case in comparison with the central station reactor sites. These factors make the conclusion all the more reasonable that all the industrialized areas studied, except for the central city regions included in the survey, would be quite favorable as nuclear process heat plant sites, at least on the basis of population risk. Siting requirements for the smaller [about $300 \mathrm{MW}(t)$ ] reactors considered for industrial energy may be less stringent than for large centrali station reactors since the small units would operate at roughly one-tenth the power and would accumulate only about one-tenth of the fission product inventory that prevalls in modern nuclear central stations.

Furthermore, it may be possible to demonstrate that the hypothetical core meltdown accident would be considerably less severe and more controllable in a small reactor. For instance, in the event of a loss of coolant design basis accident in the CNSG, whose largest primary coolant pipe outside the reactor vessel has only 10-cm (4-in.) diameter [as compared to a $71-\mathrm{cm}$ (28-in.) diameter in a large LWR], more time would be available for corrective measures, since reactor coolant would be lost at much slower rates. A detailed safety analysis of the particular type of small reactor and its containment would have to be completed in order to quantify the potential relaxation of siting restrictions.

Other aspects to be investigated would include the potential problem of reactor proliferation brought about by deployment of a large number of small reactors and the effects of industrial accidents, such as fire and explosion, on reactor safety. 


\section{ALTERNATIVE FOSSIL-FIRED STEAM SUPPLIES}

One criterion for the selection of one industrial energy supply from a number of possibilities is a choice designed to minimize economic cost to the user. Other issues such as conservation of resources, environmental effects, reliability of fuel supply, and social impacts, also must receive major consideration in the choice among industrial power sources. However, due to the limited scope of this assessment, engineering feasibility and steam costs were used as major indices of performance. The economic comparison will be focused on steam production since this form of energy constitutes a large fraction of industrial energy usage.

The engineering and cost data for coal-fired industrial steam supplies were adapted by ORNL from fairly detailed studies completed by United Engineers and Constructors in 1976, under contract to ERDA. Steam supply costs were developed by ORNL for two major types of coal, highsulfur and low-sulfur. In each instance, the thermal output in the form of process steam amounted to $365 \mathrm{MW}(t)$, the same as for the reference CNSG plant.

\subsection{Steam Generators Fueled with Eastern Bituminous Coal}

The concent of ash in coal, and its chemical composition, and fusion temperature are of great importance for proper sizing of boiler furnace, superheater and boiler tube spacing, and to establish adequate design capacity for particulate removal and ash handling systems.

Likewise, the sulfur content in coal has a great significance in the selection of an electrostatic precipitator and establishing design parameters for the flue gas desulfurization system.

Representative Eastern bituminous coals were selected for designing the high-sulfur coal plant. Coal characteristics are described in Table 3.

While the boilers are designed to burn either Coal A or Coal B, the coal and ash handling systems and electrostatic precipitators are sized for Coal A, and the flue gas desulfurization system is sized for Coal B, thus providing the plant with capability to handle either type of coal. 
Table 3. Chemical composition and properties for representative Eastern bituminous coals

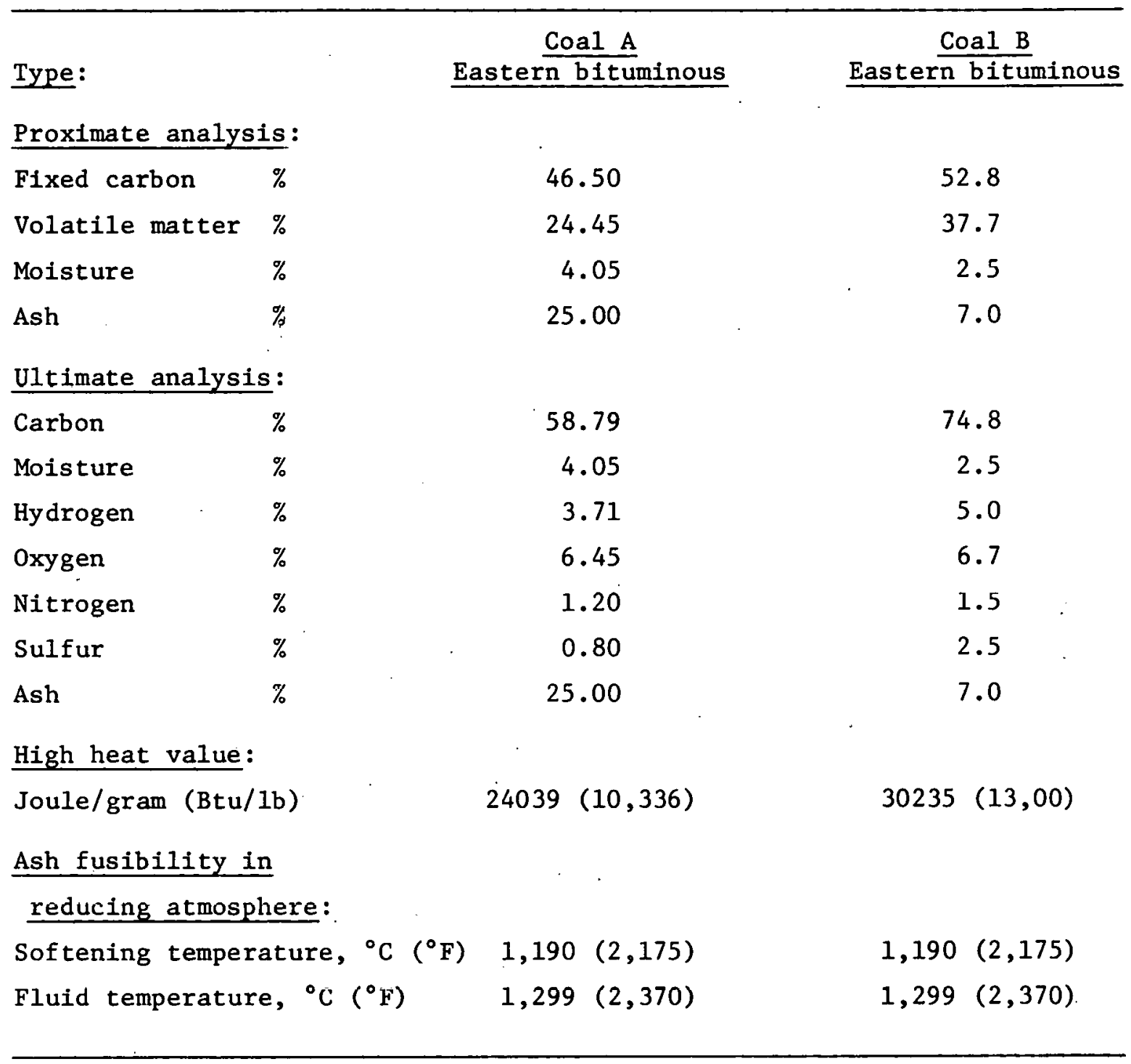

Besides burning Eastern bituminous coals, the plant is capable of burning No. 2 grade fuel oil in the event that coal supplies are interrupted.

The steam generation system comprises four $3171 \mathrm{kPa}(460 \mathrm{psi}), 399^{\circ} \mathrm{C}$ $\left(750^{\circ} \mathrm{F}\right)$ steam generators with auxiliary equipment, coal and ash handling systems, a fuel oil system, and feedwater treatment systems. The nominal steam flow rating for each unit is $31.5 \mathrm{~kg} / \mathrm{s}(250,000 \mathrm{lb} / \mathrm{hr})$, with a total process steam thermal output of $365 \mathrm{MW}(t)$ for the four boiler station. 
After particulate removal at hot flue gas electrostatic precipitators, the four flue gas streams are merged into two gas trains for desulfurization purposes before discharge to a common stack. The peak requirements of coal of the four steam generators is about 67 tons per hour $(t \mathrm{ph})$. The coal storage yard provides 96,000 tons of storage, sufficient fuel for 60 days of operation. In order to burn high-sulfur coals at the reference site and at the same time meet state and federal $\mathrm{SO}_{2}$ emission standards, provision for a flue gas desulfurization unit is necessary. The choice of system is dictated by the following factors: (1) the desirability of achieving trouble-free operation, (2) possible difficulty of marketing sulfur-containing by-products, and (3) the ready availability of a sludge disposal site on base. Based on these considerations, a choice was made of a throwaway system, specifically the FMC double alkali process, with its proven record of reliability based on clear solution scrubling.

Flyash-free flue gases from the four boilers are combined in a header that will serve as a source of flue gas for the two $\mathrm{SO}_{2}$ scrubbers. Each $\mathrm{SO}_{2}$ scrubber is designed to remove $90 \%$ of the $\mathrm{SO}_{2}$ in the entering flue gas.

In the proposed sludge fixation system, the raw sludge is transferred to a raw sludge hopper from which it is belted to a fixed sludge hopper where flyash recovered from the stack gas precipitators is added at a ratio of 0.6 mass units of flyash per mass unit $\mathrm{CaSO}_{3} \cdot 1 / 2 \mathrm{H}_{2} \mathrm{O}$ and enough pulverized lime is added to obtain a $3 \%$ lime mixture in the fixed sludge. It is estimated that a sinkhole with a volume of $1230-\mathrm{m}^{3}$ ( 960 acre-ft) would furnish a disposal area for 20 to 25 yrs of operation.

\subsection{Steam Generators Fueled with Western Low-Sulfur Coal}

The preceding discussion (Section 5.1) described a steam generating station designed for burning Eastern bituminous coals. The present section is limited to describing the major design changes required to burn Western low-sulfur coal.

Coal properties, particularly ash, have major impact on boiler design. Ash can be quite troublesome when it is heated in the combustion 
process and melts. Liquid ash sticks to boiler surfaces and volatilized ash can condense on surfaces in the convection zone of the boiler. Boiler characteristics such as furnace size and geometry, burner design and fuel input, flame clearances, sootblower locations, gas temperatures, and convection tube spacing and arrangement, must be selected so that the molten ash is kept off the boiler surfaces and becomes solidified before entering the convection surfaces. If uncontrolled, deposits can develop, interfering with heat transfer and gas flow.

In the present study, Western low-sulfur sub-bituminous coal from the Powder River Basin (Wyoming, Montana) was taken as the reference fuel for the boilers, coal handling system, and other related equipment. This type of coal is believed to be representative of low-sulfur.coal apt to be used by industry since the Powder River Basin is a major source of coal with long-term reserves. Coal chemical composition and properties are given in Table 4 .

Since the sulfur content in the Western Powder River Basin coals is low, environmental standards can be met without flue gas desulfurization systems. Therefore, $\mathrm{SO}_{2}$ removal and sludge treatment systems are not needed.

The Western Powder River Basin coals are high in moisture content and low in heat value. The coal ash properties require that the boiler. furnace be designed conservatively, and the boiler tube spacing be larger than the design for eastern coals. In order to generate $31.5 \mathrm{~kg} / \mathrm{s}$ (250, $000 \mathrm{lb} / \mathrm{hr}$ ) at each steam generator, more coal has to be burned due to the lower heat value. Consequently, the steam generators and auxiliary equipment sizes will be larger than for the plant concept described in Section 5.1 .

The peak requirements of coal of the four steam generators is about 88 tons per hour. The coal storage yard provides 127,000 tons of stor-. age, sufficient fuel for 60 days of operation. Stack gas particulates will be removed with hot flue gas electrostatic precipitators. 
Table 4. Chemical composition and properties for reference low-gulfur coals

Powder River Basin Western sub-bituminous coal Base value Minimum value

Type:

Proximate analysis:

$\begin{array}{lcccr}\text { Fixed carbun } & \% & 32.94 & 31.0 & 38.4 \\ \text { Volatile matter } & \% & 30.05 & 28.7 & 33.3 \\ \text { Moisture } & \% & 31.0 & 26.0 & 33.0 \\ \text { Ash } & \% & 6.01 & 3.1 & 7.4\end{array}$

U1timate analysis:

$\begin{array}{lcccc}\text { Carbon } & \% & 46.81 & 45.9 & 48.0 \\ \text { Molsture } & \% & 31.0 & 26.0 & 33.0 \\ \text { Hydrogen } & \% & 3.25 & 3.21 & 4.1 \\ \text { Oxygen } & \% & 11.87 & 10.4 & 13.0 \\ \text { Nitrogen } & \% & 0.66 & 0.55 & 0.80 \\ \text { Sulfur } & \% & 0.40 & 0.14 & 0.52 \\ \text { Ash } & \% & 6.01 & 3.1 & 7.4\end{array}$

High heat value:

Joule/gram (Btu/1b) $18,730(8,055) \quad 17,440(7,500) \quad 20,000(8,600)$

Ash tusibility in reducing atmosphere:
Softening temperature,
$\left({ }^{\circ} \mathrm{F}\right) \quad 1,192(2,178) \quad 1,093(2,000) \quad 1,371(2,500)$
Fluid temperature,
$\left({ }^{\circ} \mathrm{F}\right) \quad 1,213(2,215) \quad 1,149(2,100) \quad 1,371(2,500)$ 


\section{COMPARISON BETWEEN NUCLEAR AND FOSSIL-FIRED PROCESS STEAM COSTS}

\subsection{Process Steam Plant Capital Costs}

The major cost components for the CNSG and alternative coal-fired concepts are summarized in Table 5. The costs are broken down into major categories in terms of 1976 dollars - they apply to the Middletown site. Costs are shown for nth-of-a-kind plants and they include interest during construction. The single $365 \mathrm{MW}(\mathrm{t})$ CNSG generates $164 \mathrm{~kg} / \mathrm{s}$ $\left(1.3 \times 10^{6} \mathrm{lb} / \mathrm{hr}\right)$ of saturated steam, $4000 \mathrm{kPa} / 250^{\circ} \mathrm{C}\left(580 \mathrm{psia} / 483^{\circ} \mathrm{F}\right)$ via a reboiler. The coal-fired stations each comprise four boilers nominally rated at $31.5 \mathrm{~kg} / \mathrm{s} .(250,000 \mathrm{lb} / \mathrm{hr})$ each, at $3171 \mathrm{kPa} / 399^{\circ} \mathrm{C}(460$ psig $\left./ 750^{\circ} \mathrm{F}\right)$. Process steam thermal output is $365 \mathrm{MW}$ for the nuclear and the fossil-fired concepts. Total capital costs in current dollars at time of plant startup in 1985 are shown at the bottom of Table 5. An annual escalation rate of $6 \%$ was assumed beyond 1976 ; the basis of this assumption will be discussed in Section 6.3 .

\subsection{Operating, Maintenance and Fue1 Costs}

Annual operating and maintenance costs are summarized in Table 6 for the nuclear and coal-based systems. Values are given in terms of 1976 and 1985 dollars. Fuel costs are shown in Table 7. The nuclear fuel cycle costs are based on replacing about one-third of the reactor core fuel elements at intervals of 18 months.

A plant factor of 0.85 was assumed for each plant. This value appears achievable for a small nth-of-a-kind reactor operating to provide an industrial base-load. A slightly higher plant factor may be obtainable with a station using low-sulfur coal. There has been insufficient experience with $\mathrm{SO}_{2}$ stack gas clean-up systems to permit predicting, with confidence, the capacity factor of the high-sulfur coal burning plant. In terms of 1976 dollars, a $U_{3} 0_{8}$. price of $\$ 69 / \mathrm{kg}(\$ 31 / \mathrm{lb})$ and a separative work cost of $\$ 75 /$ swu were assumed for plant startup in 1985. A coal heat value of $18,600 \mathrm{~J} / \mathrm{g}(8000 \mathrm{Btu} / \mathrm{lb})$ was used for low- 
Table 5. Capital cost summary for coal-fired and nuclear plants $\left(10^{3} \$\right), 365 \mathrm{MW}(t)$ process steam output

\begin{tabular}{|c|c|c|c|}
\hline & \multicolumn{2}{|c|}{ Coal } & \multirow{2}{*}{ CNSG } \\
\hline & Low sulfur & High sulfur & \\
\hline Land and land rights & 300 & 300 & 300 \\
\hline Structures and improvements & 3,600 & 3,700 & 25,300 \\
\hline Reactor/boiler plant & 41,000 & 49,000 & 39,000 \\
\hline Electric plant & 2,500 & 3,000 & 6,500 \\
\hline Process steam reboller & & & 4,200 \\
\hline Miscellaneous plant equipment & 100 & 100 & 2,500 \\
\hline Sub-total & $\$ 47,500$ & $\$ 56,100$ & $\$ 77,800$ \\
\hline Undistributed costs $(26 \%)$ & 12,000 & 14,600 & 20,200 \\
\hline \multirow[t]{2}{*}{ Cunlingency (10\%) } & 6,000 & 7,100 & 9,800 \\
\hline & $\$ 65,800$ & $\$ 77,800$ & $\$ 107,800$ \\
\hline Interest during construction & 7,200 & 8,600 & 20,500 \\
\hline Total cost in $1976(\$ 1976)$ & $\$ 73,000$ & $\$ 86,400$ & $\$ 128,300$ \\
\hline Tnta1 rnsts in 1985 (\$1985) & $\$ 123,000$ & $\$ 146,000$ & $\$ 216,000$ \\
\hline
\end{tabular}


Table 6. Annual operating and maintenance costs for coal-fired and nuclear plants. $\left(10^{3} \$\right)$ $365 \mathrm{MW}(t)$ process steam output

\begin{tabular}{|c|c|c|c|}
\hline \multirow[b]{2}{*}{. } & \multicolumn{2}{|c|}{ Coal } & \multirow{2}{*}{ CNSG } \\
\hline & $\begin{array}{c}\text { Low sulfur } \\
18,600 \mathrm{~J} / \mathrm{g} \\
(8000 \mathrm{bb} / / \mathrm{lb})\end{array}$ & $\begin{array}{c}\text { High sulfur } \\
25,600 \mathrm{~J} / \mathrm{g} \\
(11,000 \mathrm{bbl} / 1 \mathrm{~b})\end{array}$ & \\
\hline Staff & $\$ 1,000$ & $\$ 1,400$ & $\$ 1,400$ \\
\hline Maintenance & 240 & 390 & 530 \\
\hline Supplies and expenses & 190 & 190 & 290 \\
\hline Administration and general & 120 & 180 & 240 \\
\hline Ash/sludge disposal & 510 & 2,230 & \\
\hline Nuclear insurance & & & 300 \\
\hline Facility inspection fee & & & 20 \\
\hline Total in $1976(\$ 1976)$ & $\$ 2,060$ & $\$ 4,390$ & $\$ 2,780$ \\
\hline
\end{tabular}


Table 7. Fuel cos $t s^{a}$

\begin{tabular}{|c|c|c|c|c|}
\hline \multirow{3}{*}{ In 1976 dollars } & \multicolumn{2}{|r|}{$\mathrm{Coal}^{\mathrm{b}}$} & \multirow{2}{*}{$\underline{O_{i 1} \mathrm{~b}}$} & \multirow{2}{*}{$\mathrm{CNSG}^{\mathrm{C}}$} \\
\hline & Low sulfur, $8000 \mathrm{Btu} / \mathrm{lb}$ & High sulfur, $11000 \mathrm{Etu} / \mathrm{lb}$ & & \\
\hline & & & & \\
\hline Unit cost & $20-3 C$ \$/Ton & $20-30 \$ /$ Ton & $\$ 14 / \mathrm{bb} 1$ & \\
\hline $10^{6} \$ / y r$ & $13.54-20.46$ & $9.92-14.88$ & 25.46 & 5.19 \\
\hline c/110 Btu Del. & $147-220$ & $107-160$ & 274 & 56 \\
\hline In 1985 dollars & & . & & \\
\hline Unit cost & $33.80-50.70 \$ !$ Ton & $33.80-50.70 \$ /$ Ton & $\$ 23.66 / \mathrm{bb} 1$ & \\
\hline $10^{6} \$ / y r$ & $23.05-34.58$ & $16.76-25.15$ & 43.03 & 8.77 \\
\hline$c / 10^{E}$ Btu Del. & $248-37 ?$ & $161-270$ & 463 & 95 \\
\hline
\end{tabular}

a Plant factor 0.85

$b_{\text {Boiler efficiency } 85 \%}$

$\mathrm{C}_{3} \mathrm{O}_{8}$ price $\$ 31 / 1 \mathrm{~b}$, separative work cost $\$ 75 / \mathrm{swu}$

dEscalation $1976-1985,6 \%$ per year

Multiply Btuilb by 2.3258 to obtain J/g Multiply $c / 10^{6}$ Btu by 1.055 tc obtain $c / 10^{6} \mathrm{~kJ}$ Multiply $\$ / 1 \mathrm{~b}$ bo 2.204 to obtain $\$ / \mathrm{kg}$ 
sulfur coal, and $25,600 \mathrm{~J} / \mathrm{g}(11,000 \mathrm{Btu} / 1 \mathrm{~b})$ for the high-sulfur fuel. Boiler thermal efficiency was taken as $85 \%$ for the coal-fired plants. A range of coal prices of $\$ 20$ and $\$ 30$ per ton ( $\$ 1976$ ) was selected to account for the uncertainty in coal prices due to market conditions and due to variations in regional coal transportation costs. Recent contract prices for the delivery of high-sulfur and low-sulfur coal in the 1976-77 period have often fallen into this range. The above range of coal costs is equivalent to $\$ 0.95-1.43$ per $\mathrm{kJ}\left(\$ 0.90-1.36\right.$ per $\left.10^{6} \mathrm{Btu}\right)$ for high-sulfur coal in (\$1976) - corresponding values for low-sulfur coal are $\$ 1.32-1.97$ per $\mathrm{kJ}\left(\$ 1.25-1.87\right.$ per $\left.10^{6} \mathrm{Btu}\right)$.

For comparison purposes, the cost of process steam generated in new oil-fired boilers was included in the analysis - a value of $\$ 14 /$ barrel ( $\$ 2.46$ per $\mathrm{kJ}$ or $\$ 2.33$ per $10^{6} \mathrm{Btu}$ ) for fuel cost was selected as representative of 1976 prices. A constant annual escalation of $6 \%$ per year beyond 1976 was again used to determine fuel costs at the time of plant start-up in 1985 and during the operating period.

\subsection{Calculations}

Economic comparisons of alternative energy sources that operate. over extended time periods are often ambiguous because economic inflation can produce major changes in important cost components. Inflation will have different effects on the various costs that comprise the price of industrial energy. In the absence of changes in real costs, staff wages, replacement parts, and fuel will tend to increase at prevailing inflation rates - however, the fixed charges for capital obtained with long-term financing will remain relatively unchanged. Thus, a given rate of inflation will tend to raise the cost of energy from energy sources with a large fuel cost (such as oil-fired boilers) relative to the cost of energy from sources with large capital costs (such as nuclear reactors).

For the present energy cost comparison, a computer program was developed to account explicitly for the effects of inflation in an internally consistent way. This method gives an estimate of the relative economice of varinus power sources in an inflationary environment. For 
more detailed analyses, each industrial user would probably wish to use established "in house" techniques.

In the present economic evaluation, the cost of capital was taken as $8.3 \%$ for debt and $15.3 \%$ (after taxes) for equity - these values are believed representative of current yields for the Chemicals and Petroleum Refining industries. Implicit in these yields is the expectation that economic inflation will continue into the foreseeable future. Current expectations for future inflation range from about 5 to $7 \%$ - in the present analysis, an average value of $6 \%$ inflation per year was assumed.

The following items were assumed subject to a constant annual rate of inflation; fuel cost, operating and maintenance costs, and property insurance. Other expenses were assumed not to escalate beyond the time of plant start-up. The tax depreciation allowance also was taken as noninflating.

The financial method used by potential industrial energy users will depend on the particular company's financial structure. The impact of the debt/equity ratio on steam cost was assessed by considering ratios of $0.25 / 0.75$ and $0.75 / 0.25$. The cost of financing capital outlays will be less if extensive use is made of bond financing because the return on bonds is lower than on equity and besause the interest pald on bunds is deductible for Federal Income Tax purposes.

Plant starl-up for each alternative power source was set for $1985-$. steam costs were calculated in terms of $\$ 1985$. Capital costs for 1985 are based on 1976 costs inflated at $6 \%$ per year from 1976 to 1985 as shown on Table 5 .

Amortization periods of $5,10,20$, and 30 years were examined, spanning the range that might be of interest to most industrial energy users. The computer calculation determines annual cash flows for the following expenses:

1. fuel

2. operation and maintenance

3. property insurance

4. property tax

5. state income tax

6. federal income tax

7. depreciation

8. interest

9. return on equity capital 
All components of construction cost (direct and overhead) are capitalized and expressed as a single capital expenditure at time of plant start-up.

The state income tax rate is assumed to apply to operating revenue minus the expenses of fuel, O\&M, property insurance, property tax, and interest, and an assumed depreciation allowance for state tax purposes. Federal income tax calculations are the same as state tax calculations except that state income taxes are deductible from federal income taxes, while federal income taxes are not deductible from state taxes. Federal and state tax rates were $48 \%$ and $4 \%$ respectively. Property tax was calculated on a nondepreciating basis with a rate of $0.6 \%$. Tax payments were permitted to be negative; it was assumed that other parts of the corporation would have compensating tax expenses. A $10 \%$ investment tax credit was taken. Sum-of-the-years-digit depreciation for federal and state income tax was used with a tax life of $80 \%$ of plant life in each case.

The following quantities are calculated by the computer program in order to derive the steam cost:

1. The present worth of all annual expenditures discounted at the firm's weighted average cost of capital (debt and equity).

2. The present worth of required revenues to meet the expenses of (1). Revenues are therefore just sufficient to cover expenses and provide the required return to investors, depreciation, and to pay back all capital by the end of the project.

3. Ihe constant annual revenue (constant in terms of $\$ 1985$ ), which when discounted to time of plant start-up at the firm's weighted average cost of capital, provides the same present worth of expenditures as in (1) above. The revenue, divided by the amount of process heat produced annually, yields the cost of process steam.

In terms of $\$ 1985$, the process steam cost calculated according to the procedure outlined in step (3) remains constant during the life of the plant. In terms of current dollars, these costs escalate at the prevailing inflation rate $-6 \%$ per year in this analysis. 


\subsection{Results}

Process steam costs calculated for the nuclear and fossil-fired options are shown in Figs. 5 and 6. A number of conclusions can be drawn:

(1) If project capital must be amortized within 5 to 8 years, oil is an attractive fuel relative to coal and nuclear. As the capital amortization period lengthens, nuclear and coal become more attractive.

High debt/equity ratios favor the nuclear capital intensive option. This is reflected in the effective fixed charge rates obtained from the cash flow analysis - the fixed charge rates are $18.7 \%$ and $11.2 \%$ for debt-equity ratios of $25 / 75$ and $75 / 25$ respectively for a 20-yr amortization period. (3) For the lower end ( $\$ 20 /$ ton in \$1976) of the coal price range and. with predominant equity financing, coal and nuclear plants produce steam at roughly identical costs - nuclear is more attractive with predominant bond financing. (4) Relative to higher priced coal ( $\$ 30 /$ ton In \$1976) nuclear yields lower steam costs for both debt-equity ratios examined. Hence, for a 20-yr capital amortization period, the 1985 present worth of the cost savings of nuclear over coal amount to \$110 million and \$197 million for debt-equity ratios of $25 / 75$. and $75 / 25$, respectively. These savings amount to 21 and $33 \%$ of the present worth of the coal fired project costs.

These conclusions are based on an analysis that incorporated a number of simplifying assumptions on site conditions, power output, and project financing. The alternative power sources were treated primarily as integral steam supplies with analysis of dual-purpose applications set aside for later site oriented studies. These studies will provide a more definitive economic assessment of small industrial reactors since they will include more detailed treatment of engineering and economic aspects.

Significant outlays may bc required lo cuuple the reactor to the industrial processes. For a retrofit application, some existing industrial equipment may have to be adapted to the reactor steam conditions. Fossil-fired back-up capability would involve additional costs to the industrial user - these costs may be minor for reactor applications at existing industrial sites that already have fossil-fired power sources. 


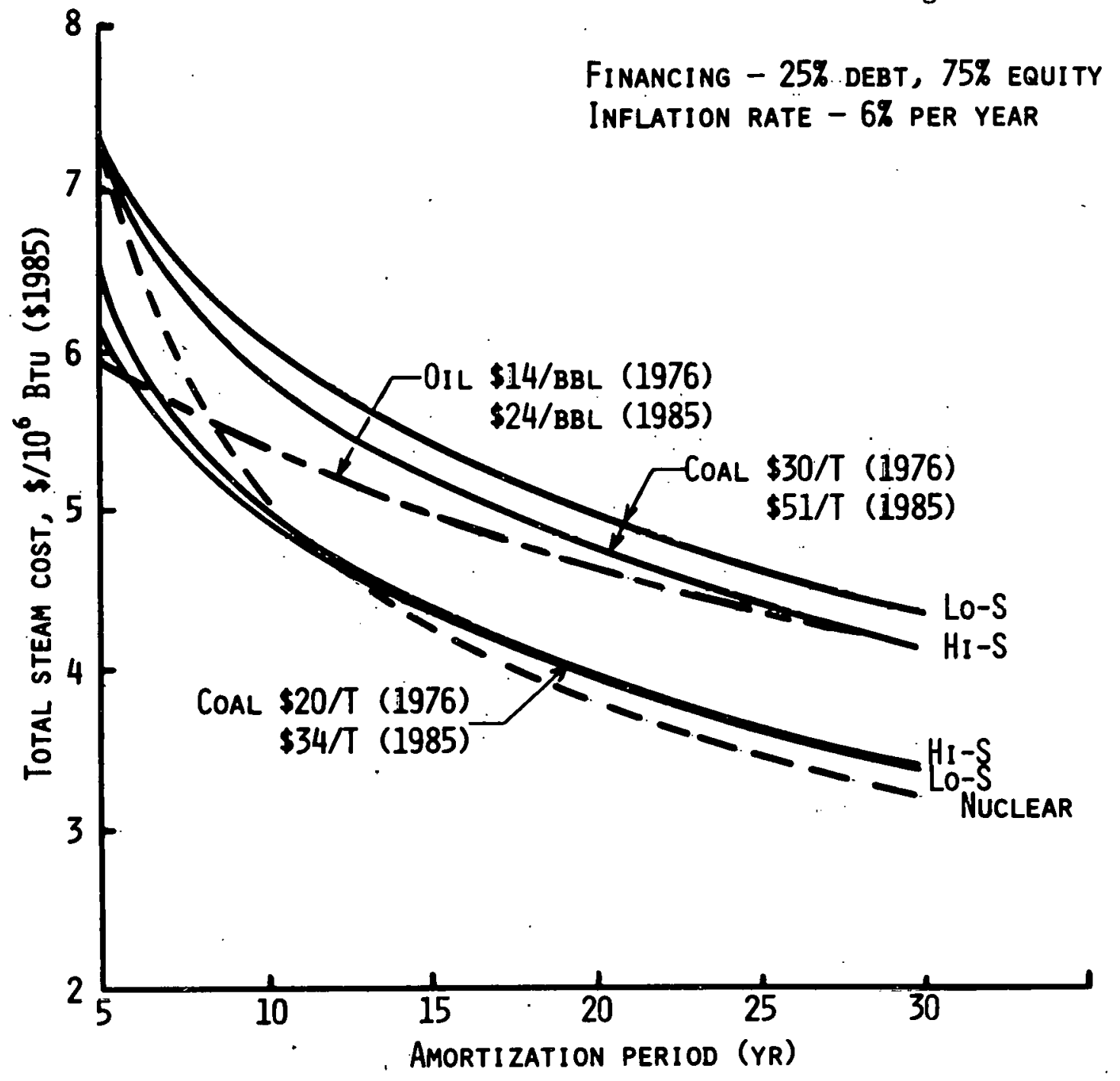

Fig. 5. Nuclear and Fossil-fired steam costs for debt/equity ratio of $25 / 75$. 
ORNL Dwg. 77-8544

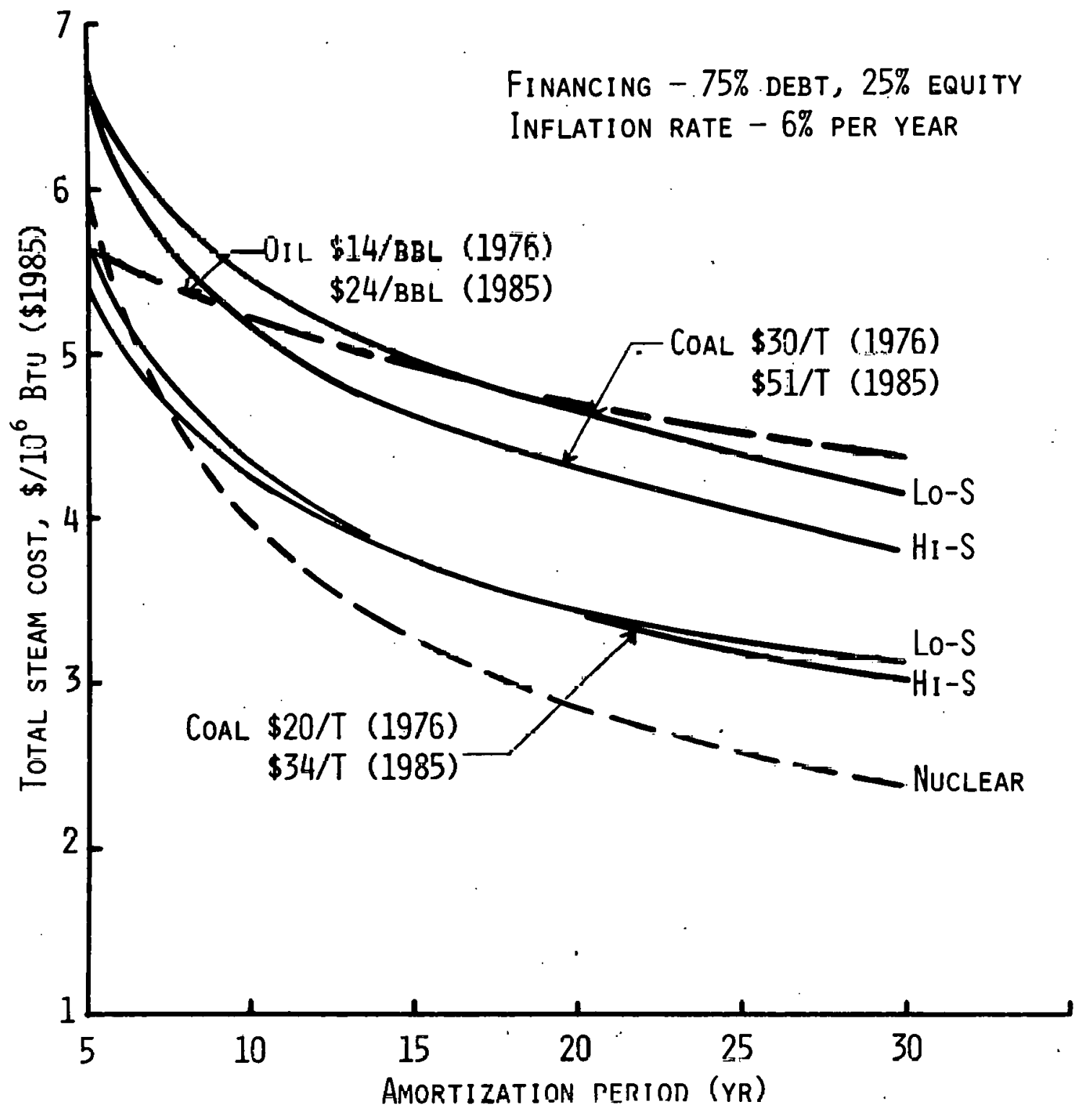

Fig. 6. Nuclear and fossil-fired steam costs for debt/equity ratio of $75 / 25$. 
Many industrial plants would also require some electrical power in addition to process steam - thus a comparison of nuclear and fossil-fired alternatives may also have to include the cost of back pressure or extraction turbine generator systems.

These investigations are planned for a subsequent study phase that will examine reactor applications at specific representative industrial sites in cooperation with potential industrial users. The cost analyses in these studies will use the particular amortization periods, returns on investment, tax accounting, projected inflation rates, and other economic parameters customarily used by these concerns to evaluate new investments - thus, these future assessments of energy options may differ from the judgments presented above. 


\section{FIRST-OF-A-KIND COSTS}

The nuclear plant costs shown in Table 5 and the overall economic comparison made in Section 6 are based on the nth-of-a-kind costs and thus include no first-of-a-kind expenses.

First-of-a-kind (FOAK) work is defined as follows: Those work activities which are non-repetitive for follow-on units including engineering, licensing, and test and evaluation efforts required to develop design parameters, demonstrate safety to the regulatory authorities, and verify design adequacy.

A preliminary listing of the tasks comprising the first-of-a-kind effort and a crude estimate of the associated costs were taken from Ref. 13 as follows.

A. Engineering

1. Development of Reactor Plant baseline design (component and system specifications and drawings).

2. Design analyses required to satisfy regulatory agencies.

3. Development of Reactor Plant test, startup, and operating :procedures.

4: Development of special manufaceur1ng procedures inciuding A3ME cude cidses.

5. Architectural and construction design.

6. Development of Power Plant systems and equipment designs.

7. Power Plant layout design.

8. Development of Power Plant test, startup, and operating procedures.

9. Support to test and evaluation programs.

10. Development of special containment manufacturing procedures for shop and. field.

11. Design of special tools.

B. Tests and Evaluations

These items are discussed in Section 4.3.

C. Licensing Support

The following support to be provided to the licensing applicant:

1. Resolution of general regulatory issues related to the class of reactors 
2. Support environmental studies and reports relative to the reactor plant.

3. Prepare and submit PSAR to NRC.

4. Obtain limited work authorization for start of construction.

5. Prepare and submit FSAR to NRC.

6. Obtain commercial operating license.

7. Prepare and submit environmental reports in support of environmental impact statements.

The reactor plant FOAK costs are estimated to be approximately 40 to 48 million dollars. This figure assumes that the maritime CNSG (MCNSG) does not precede the process energy CNSG (PE-CNSG). If the M-CNSG should precede the PE-CNSG and if all FOAK costs are covered under the M-CNSG program, then the FOAK costs unique to the PE-CNSG would be approximately 7 to 10 million dollars. A shared approach to the FOAK costs is a possibility if these two programs should proceed simultaneously. Included in the 40 to 48 million dollars FOAK costs identified above is a figure of 7 to 9 million dollars for test and evaluation. This cost assumes that the PE-CNSG precedes the M-CNSG and is charged all of the test and evaluation costs. If the M-CNSG should precede the PE-CNSG and if all FOAK test and evaluation costs are covered under the M-CNSG program, then the FOAK test and evaluation costs unique to the PE-CNSG would be approximately 1 million dollars and is included in the 7 to 10 million dollars FOAK cost described above. 


\section{8: INDUSTRIAL ACCEPTANCE}

The application of nuclear reactors to provide process energy poses a number of unique problems and benefits that are difficult to assess in strictly economic terms. Some of these will be briefly discussed here.

Reactors are highly capital intensive and even relatively small ones [300-400 MW(t)] involve investments in excess of a hundred million dollars. This amount is much greater than the cost of the gas- or oil-fired boilers used at the present time, and thus industrial reactors (or coalfired boilers) can impose a major strain on the financial resources of the owner. The planning and financing horizons in industry range from 5 to 10 years - obviously a very short time to pay off the large reactor investment. Thus, a longer-range view may need to be taken in financing industrial reactors, so that capital recovery can be spread over the operating life of the power source.

Uncertainties about future energy costs and fuel availability have made industry reluctant to proceed rapidly with construction of alternative power sources for replacing gas- and oil-fuels. Contributing factors include an inability to predict oil prices imposed by OPEC, uncertainties about the effect of environmental and legal constraints on the availability of coal and/or the cost of extracting energy from this fuel. It is quite likely, therefore, that industry will be particularly reluctant to make large and long-term investments in industrial power plants as long as these major uncertainties persist. Establishment of a broadbased national policy on industrial energy would doubtlessly encourage industry to proceed with alternative sources of process energy.

Large reactors currently require 8 to 10 years for completion. In contrast, major petroleum refining and chemical plants that might use nuclear process energy are often built in only 3 to 5 years. The mismatch in project schedules would be less for small reactors, since these units could be built more quickly. A study by Babcock and Wilcox ${ }^{5}$ indicates that an nth-of-a-kind CNSG reactor might be completed in about 6 years - even this accelerated schedule is much longer than the time needed to build oil- or gas-fired industrial boilers. Delay in completing an industrial reactor on time could result in a major loss of industrial 
production, thus, extensive use of nuclear energy for industry must go hand in hand with the ability to predict nuclear plants' construction schedules. Development of a small industrial reactor of standard design that is compatible with a wide range of industrial energy requirements and site characteristics might achieve this objective.

The major potential advantage of nuclear energy over conventional industrial energy sources lies, of course, in the low cost of nuclear fuel. A further advantage to an industrial user is the relatively sma11 fraction of the total energy cost that represents fuel costs. Thus, future increases in nuclear fuel costs would raise the cost of nuclear electricicy/steam only a modest amount. The cost of energy produced with nuclear can therefore be expected to remain more stable over the long term than the cost of energy from fossil fuels.

Nuclear reactors could provide a relatively assured supply of industrial energy since reactors are refueled infrequently and replacement fuel is procured on a long-term basis. Thus, nuclear industrial energy systems would be relatively immune to disruptions caused by oil embargoes, or by strikes in the fuel production/transportation sectors of industry.

As a replacement for petroleum-based fuels, nuclear offers an advantage over coal burning units in that operation of a reactor plant does not deteriorate air quality. This feature may be of major importance in heavily industrialized regions where further deterioration of air quality is not permitted, yet where alternative sources of industrial energy are needed to replace petroleum-based fuels.

An industrial CNSG unit would occupy less land area than an equivalent coal-fired station with its coal handling and storage facilities. This factor could be significant for applications at congested industrial sites where land is scarce and costly. Requirements for reactor exclusion or controlled area must be considered. 


\section{CONCLUSIONS AND RECOMMENDATIONS}

The potential market for small industrial reactors in the U.S. Is sizable - 119 sites have been Identified in the paper, chemicals, petroleum, rubber and primary metals industries with process steam requirements compatible with the CNSG plant.

The level of steam supply reliability observed recently in several major industries appears attainable with either multiple nuclear or a combination of nuclear and fossil-fired units. Fossil-fired back-up capability would involve additional costs to the industrial energy user these costs may be minor for reactor applications at existing industrial sites that already have fossil-fired power sources.

The land-based configuration of the CNSG offered lower energy cost than barge-mounted designs - future CNSG industrial reactor studies will therefore focus on land-based applications.

The CNSG design is based on current technology and relatively little development is required. Some component proof tests and other tests to confirm adequacy of the CNSG design would be required. Development and first-of-a-kind costs are somewhat uncertain - they are believed to be in the range of 40 to 48 million dollars ( $\$ 1976)$. These costs might amount to only 7 to 10 million dollars if the developmental efforts aimed at CNSG Maritime reactors were to be integrated into a CNSG industrial applications program.

A preliminary survey of population distribution in 11 representative industrially developed areas in Texas and Louisiana has shown that most of these regions could meet the population separation distance requirements for nuclear reactors. Industrial reactors may require special protection against industrial fire and explosion. Siting requirements for the CNSG may be less stringent than for large central station reactors since the small unit would operate at roughly onetenth the power and would accumulate only about one-tenth of the fission product inventory that prevails in modern nuclear central stations, and because the unit's compact design may lessen the severity of a lossof-coolant accident. 
Project amortization periods need to be about 10 years or longer in order for nuclear steam costs to be attractive. High debt/equity ratios for financing nuclear projects appear advantageous. In regions with high ( $\$ 30 /$ ton) coal costs, the nuclear option offers potential cost reductions in the range of $21-33 \%$ relative to coal-based process steam.

It is recommended that reactor feasibility be studied at specific reprèsentative industrial sites in order to develop a realistic basis for gauging the commercial viability of small industrial reactors. Cogeneration of electricity to meet the industrial users' power requirement will need to be considered in these evaluations.

Uncertainties in reactor project schedules and in the licensing process present a major obstacle to industrial acceptance of process energy reactors. It is our judgment that project schedules must be predictable if industrial reactors are to become a viable option. Development of a standard nuclear industrial plant suitable for a wide range of applications should ease licensing and construction procedures and contribute toward a shortened project schedule. 


\section{REFERENCES}

1. T. D. Anderson et al., An Assessment of Industrial Energy Options Based on Coal and Nuclear Systems, ORNL-4995 (July 1975).

2. $\quad$. H. Klepper, "Nuclear Dual-Purpose Plants for Industrial Energy," proceedings, Eleventh Inter-Society Energy Conversion Engineering Conference, held at Stateline, Nevada, Sept. 12-17, 1976.

3. H. G. MacPherson and O. H. Klepper, "Small Reactors for Process Heat," proceedings of the First National Topical Meeting on Nuclear Process Heat Applications, LA-5795-C (CONF-741032), Los Alamos, New Mexico, Oct. 1-3, 1974.

4. O. H. Klepper, "Small Nuclear Reactors for Industrial Energy," presented at the Industrial Power Conference, Memphis, Tennessee, May $17-19,1976$

5. A Small Pressurized Water Reactor for Process Energy, prepared by Babcock and Wilcox under contract to the Oak Ridge National Laboratory, Report No. BAW-1428 (ORNL/SUB/4390-2) (June 1976).

6. The Potential Industrial Market for Process Heat from Nuclear Reactors, prepared by Dow Chemical U.'S.A., under contract to the Oak Ridge National Laboratory, ORNL/TM-5516 (July 1976).

7. W. G. Sullivan and T. M. West, Process Energy Reliability Requirements for Selected Industries, ORNL/TM-5428 (September 1976).

8. W. G. Sullivan, J. V. Wilson, and 0. H. Klepper, Reliability Estimation for Multi-Unit Nuclear and Fossil-fired Industrial Energy Syotcmo; ORNL/TM 5837 (to be publighed).

9. O. H. Klepper and W. R. Smith, "Studies of a Small PWR for Onsite Industrial Power," presented at The American Power Conference, 39th Annual Meeting, Chicago, Illinois, April 19, 1977.

10. Preliminary Safety Analysis Report, Competitive Nuclear Merchant Ship Program, MA-940-02, prepared for the U.S. Maritime Administration by Babcock and Wilcox (April 1974).

11. Siting Study for Sma11 Platform-Mounted Industrial Energy Reactors, prepared by Gibbs and Hill, Incorporated, for the Oak Ridge National Laboratory (July 1975).

12. Barge-Mounted Nuclear Power Plant Study, prepared by George C. Sharp, Incorporated, for the Oak Ridge National Laboratory (June 28, 1974).

13. PE-CNSG Site and Application Study, prepared by Babcock and Wilcox under contract to Oak Ridge National Laboratory (to be published). 
ORNL/TM-5881

\author{
INTERNAL DISTRIBUTION
}

$\begin{aligned} \text { 1. } & \text { T. D. Anderson } \\ 2 . & \text { S. Baron } \\ 3 . & \text { T. E. Cole } \\ \text { 4. } & \text { F. L. Culler } \\ \text { 5. } & \text { J. G. Delene } \\ 6 . & \text { G. G. Fee } \\ 7 . & \text { L. C. Fuller } \\ \text { 8. } & \text { J. F. Harvey } \\ 9 . & \text { J. E. Jones } \\ 10 . & \text { M. A. Karnitz } \\ 11-19 . & \text { O. H. Klepper } \\ 20 . & \text { M. Levenson } \\ 21 . & \text { M. L. Myers }\end{aligned}$

22. M. O1szewski

23. H. Postma

24. M. W. Rosenthal

25. Dunlap Scott

26. M. R. Sheldon

27. M. J. Skinner

28. I. Spiewak

29. D. B. Trauger

30-31. Central Research Library

32. Document Reference Section

33-35. Laboratory Records Dept.

36. Laboratory Records (RC)

\title{
EXTERNAL DISTRIBUTION
}

37. S. L. Adams, Gulf States Utilities, P.0. Box 2951, Beaumont, Texas 77704

38. Ismael Almodovar, Center for Energy and Environment Research, University of Puerto Rico, Caparra Heights Station, San Juan, Puerto Rico 00935

39. Seymour Alpert, Electric Power Research Institute, 3412 Hillview Ave., Palo Alto, Calif. 94304

40. William J. Amos, Senior Strategic Planner, Energy Systems Dept., Cryogenic Systems Div., Air Products and Chemicals, Inc., P.0. Box 538, Allentown, PA 18105

41. Joseph M. Anderson, Dir., Division Development, Chemical Division, PPG Industries, Inc., 1 Gateway Center, Pittsburgh, PA 15222

42. R. W. Barnes, Dow Chemical Co., 2040 Dow Center, Midland, Mich. 48640

43. Theodore Beresovski, ERDA Scientific Representative, Science Office, American Embassy, 2 Rue Gabriel, 75382 Paris, France

44. D. J. Blickwede, Bethlehem Steel Corp., Bethlehem, PA 18016

45. James B. Borden, Mgr. Special Studies, Energy \& Materials Dept., E. I. duPont de Nemours \& Co., Wilmington, De1. 19898

46. D. E. Cabrilla, Environmental Protection Agency (AW-459) $401 \mathrm{M} \mathrm{St}$. SW, Washington, D.C. 20460

47. S. N. Cavros, Div. of Conservation, ERDA, Washington, D.C. 20545

48. J. T. Cockburn, Program Manager, Fuel Conversion Project, Celanese Chemical Co., 777 South Post Oak Road, Houston, Texas 77056

49: R. L. Cowles, Federal Energy Agency, 1200 Pennsylvania Ave., Washington, D.C. 20461

50. J. Crowley, United Engineers and Constructors, Inc., 1401 Arch St., Philadelphia, PA 19105

51. Don Dean, Mgr. Utilities Engineering, Diamond Shamrock Corp., Culf Coast Area, 1149 Ellsworth Drive, Pasadena, Texas 77501 
52. J. F. Dinwiddie, Division of Fossil Energy, ERDA, Washington, D.C. 20545

53. D. E. Erb, Division of Nuclear Research and Applications, ERDA, Washington, D.C. 20545

54. Efrain Friedman, Energy Advisor, International Bank for Reconstruction and Development, 1818. "H" Street NW, Washington, D.C. 20433

55. Thomas Gamble, Engineering Dept., Hercules, Inc., 9th and Market Streets, Wilmington, Del. 19899

56. M. W. Golay, Dept. of Nuclear Engineering, Massachusetts Institute of Technology, 138 Albany St., Cambridge, Mass. 02139

57. Dan Greeno, Dir., Energy Management, Stauffer Chemical Co., Westport, Conn. 05880

58. Tom Gross, Office of Conservation and Environment, Federal Energy Agency, 1200 Pennsylvania Ave., Washington, D.C. 20461

59. H. L. Harkins, Power Systems Engineering, Inc., P.0. Box 19398, Houston, Texas 77024

60. Doug Harvey, Asst. Dir., Division of Industrial Energy Conservation, ERDA, Washington, D.C. 20545

61. H. R. Irvine, Senior Advisor Feedstock/Fuels Division, Exxon Chemical Co. USA, 1333 West Loop South, Houston, Texas 77027

62. D. R. Israel, Program Integration, ERDA, Washington, D.C. 20545

63. A. E. Kakretz, Mgr., Gas Reactor Development, General Electric Co., Fairfield, Conn. 06430

64. J. Karkheck, Brookhaven National Laboratory, Upton, L.I., N.Y. 11973

65. L. Loughridge, Corporate Energy Conservation Coordinator, American Cyanamid Co., Bearden Ave., Wayne, N.H. 07470

66. Robert McFarren, Federal Energy Agency, 1200 Pennsylvania Avenue, Washingt on, D.C. 20461

67. A. T. McMain, General Atomic Co., P.0. Box 81608, San Diego, Calif. 92138

68. H. G. MacPherson, Institute for Energy Analysis, Oak Ridge Associated Universities, F.0. Dox 117, Oak Ridge, TN 37830

69. P. L. Maisto, Director, Energy Feedstock Department, BASF Wyandotte Corp., P.O. Vox 181, Parsippany, N. J. 07054

70. Robert E. Mathe, Inter-American Development Bank, 808 17th St. $\dot{\mathrm{N}} \bar{W}$, Washington, D.C. 20577

71. Richard F, Messing, A. D. Little, Inc., Acorn Park, Cambridge, Mass. 02140

72-81. R. G. Oehl, Division of Nuclear Research and Applications, ERDA, Washington, D.C. 20545

82. R. G. Prather, ERDA, 20 Massachusetts Avenue, Washington, D.C. 20545

83. Richard B. Pool, Energy Coordinator, Kaiser Aluminum \& Chemical Corp., 300 Lalccoldc Dr., Oakland, Calif. 9/16/3

84. James Ragland, Staff Engineer, She11 0il Co., P.0. Box 2463, Houston, Texas 77001

85. J. L. Renzetti, Naval Nuclear Power Unit, 13101 Pelfrey Ln., Fairfax, VA 22030

86. W. R. Smith, Power Generac1on Group, Babcock \& W1lcox Co., P.O. Bux 1260, Lynchburg, VA 24505

87. John S. Sorice, Director, Project Planning, Olin Chemicals, 120 Long Ridge Road, Stamford, Conn. 06904 
88. George Story, Research and Technology Div., U.S. Army Facilities Engineering Support Agency, Fort Belvoir, VA 22060

89. A. J. Streb, Division of Industrial Energy Conservation, ERDA, Washington, D.C. 20545

90. W. G. Sullivan, Department of Industrial Engineering, University of Tennessee, Knoxville, TN 37916

91. R. D. Sweeney, E.I. duPont deNemours \& Co. P.0. Box 2626, Victoria, Texas 77901

92. R. L. Thompson, Federal Energy Agency, 1200 Pennsylvania Avenue, Washington, D.C. 20461

93. Seth Tuttle, Program Manager (SIA), National Science Foundation, 1800 G Street NW, Washington, D.C. 20550

94. R. F. Ward, Vice President, Hooker Chemical Corp., P.0. Box 61569, Houston, Texas 77208

95. A. M. Weinberg, Institute for Energy Analysis, Oak Ridge Associated Universities, P.0. Box 117, Oak Ridge, TN 37830

96. R. W. Wendes, Amoco 011 Co., M.C. 1105, Box 6110Z, Chicago, Ill. 60680

97. R. L. Wright, Manager, Energy Systems, Long Range Planning, Union Carbide Corp., P.0. Box 186, Port Lavaca, Texas 77979

98. Director, Division of Nuclear Research and Applications, ERDA, Washington, D.C. 20545

99. Director, Reactor Division, ERDA, ORO

100. Research and Technical Support Division, ERDA, ORO

101-127. Technical Information Center, ERDA, ORO 